\title{
Satış Promosyonları ve Kredi Kartı Kullanımının Tüketicilerin Plansız Satın Alma ve Satın Alma Sonrası Pişmanlık Davranışı Üzerindeki Etkileri (The Effects of Sales Promotion and Credit Card Usage on Consumers' Unplanned Buying and Post-Purchase Regret Behavior)
}

\section{Erkan ÖZDEMIR (iD a Serkan KILIÇ iD $\mathrm{b}$ Mehmet Akif ÇAKIRER iD $\mathrm{c}$}

a Bursa Uludağ Üniversitesi, İktisadi ve İdari Bilimler Fakültesi, İşletme Bölümü, Bursa/Türkiye, e-posta: eozdemir@uludag.edu.tr b Bursa Uludağ Üniversitesi, İktisadi ve İdari Bilimler Fakültesi, İşletme Bölümü, Bursa/Türkiye, e-posta: skilic@uludag.edu.tr c Afyon Kocatepe Üniversitesi, Bolvadin Meslek Yüksekokulu, İşletme Programı, Afyon/Türkiye, e-posta: cakirer@aku.edu.tr

\begin{tabular}{|c|c|}
\hline MAKALE BİLGİSİ & ÖZET \\
\hline $\begin{array}{l}\text { Plansız Satın Alma Davranışı } \\
\text { Satın Alma Sonrası Pişmanlık } \\
\text { Davranışı } \\
\text { Satış Promosyonları } \\
\text { Kredi Kartı Kullanımı } \\
\text { Yapısal Eşitlik Modellemesi } \\
\text { Gönderilme Tarihi } 2 \text { Eylül } \\
2019 \\
\text { Revizyon Tarihi } 10 \text { Kasım } 2019 \\
\text { Kabul Tarihi } 15 \text { Kasım } 2019\end{array}$ & $\begin{array}{l}\text { Amaç - Pazarlamanın amacı tüketicilerde talep yaratmak ve talebi yönetmektir. Talebin } \\
\text { yaratılmasında satış promosyonları ve tüketicilerin kredi kartı kullanabilme imkânları bu noktada } \\
\text { önemli bir role sahiptir. Bu çalışmanın amacı, satış promosyonları ve tüketicilerin nakitleri olmasa } \\
\text { da kredi kartıyla alışveriş yapabilmelerinin tüketicilerin plansız satın alma davranışlarına ve satın } \\
\text { alma sonrasında pişmanlık davranışlarına etkilerini ortaya koymaktır. Ayrıca plansız satın almanın } \\
\text { aracı değişken olarak, cinsiyetin de düzenleyici değişken olarak etkileri oluşturulan model } \\
\text { çerçevesinde araştırılmaktadır. } \\
\text { Yöntem - Araşırıma, } 1 \text { Nisan } 2018 \text { ve } 21 \text { Mayıs } 2018 \text { tarihleri arasında gerçekleştirilmiştir. } \\
\text { Araştırmada kolayda örnekleme yöntemi kullanılmıştır. Araştırma modeli Smart PLS kullanılarak } \\
\text { yapısal eşitlik modellemesiyle test edilmiştir. } \\
\text { Bulgular - Araştırma sonucunda, satış promosyonlarının ve kredi kartıyla alışveriş yapabilmenin } \\
\text { tüketicilerin plansız satın alma davranışında ve satın alma sonrası pişmanlık davranışında } \\
\text { doğrudan etkilerinin olduğu bulunmuştur. Çalışmada plansız satın almanın aracılık etkisi } \\
\text { araştırılmış, ancak plansız satın almanın aracılık etkisi bulunmamıştır. Ayrıca modelde cinsiyetin } \\
\text { bir moderatör değişkeni olarak etkisi de araştırılmış ve satış promosyonlarını etkisinin kadınların } \\
\text { planlanmamış satın alma davranışları üzerinde, satın alma sonrası pişmanlık davranışları } \\
\text { üzerindeki etkisi de erkeklerde daha yüksek bulunmuştur. } \\
\text { Tartışma - Tatmin ve sadakat düzeyi yüksek müşterilere sahip olmak isteyen işletme yöneticileri, } \\
\text { müşterilerinin satın alma sonrası pişmanlık duymamaları için satış promosyonlarını ve kredi kartı } \\
\text { seçeneklerini dikkatli kullanmalıdırlar. }\end{array}$ \\
\hline
\end{tabular}

\begin{tabular}{|c|c|}
\hline ARTICLE INFO & ABSTRACT \\
\hline Keywords: & $\begin{array}{l}\text { Purpose - The purpose of marketing is to create and manage consumer demand. Sales promotions } \\
\text { and the ability of consumers to use credit cards play an important role in the creation of demand. }\end{array}$ \\
\hline Unplanned Purchasing & The purpose of this study is to put forward that the effects of sales promotions and the ability of \\
\hline Behavior & consumers to make purchases by credit card, even if they do not have cash, on the consumers' \\
\hline Post-Purchase Regret Behavior & unplanned buying behavior and the post-purchase regret behavior. In addition, the effects of \\
\hline Sales Promotions & unplanned buying as a $\mathrm{n}$ \\
\hline Credit Card Usage & the framework of the model. \\
\hline Structural Equation Modeling & Design/methodology/approach - The research was conducted between 1 April 2018 and 21 May \\
\hline Received 2 September 2019 & $\begin{array}{l}\text { 2018. The convenience sampling method was used in this study. The research model was tested with } \\
\text { structural equation modeling by using Smart PLS. }\end{array}$ \\
\hline Revised 10 November & Results - As a result of the research, it was found that sales promotions and shopping by credit card \\
\hline Accepted 15 November & $\begin{array}{l}\text { had direct effects on the unplanned buying behavior and the consumers' post-purchase regret. In } \\
\text { the study, the mediation effect of unplanned buying behavior was investigated, but no mediation }\end{array}$ \\
\hline \multirow{4}{*}{$\begin{array}{l}\text { Article Classification: } \\
\text { Research Article }\end{array}$} & effect of unplanned buying was found. In the model, the effect of gender as a moderator variable \\
\hline & was also investigated. The effect of sales promotions was found to be higher on unplanned buying \\
\hline & behavior of females, and the higher on post-purchase regret behavior in males. \\
\hline & $\begin{array}{l}\text { Discussion - Business managers who want to have customers with high levels of satisfaction and } \\
\text { loyalty should use sales promotions and credit card options carefully so that their customers do not } \\
\text { regret their purchases. }\end{array}$ \\
\hline
\end{tabular}




\section{GİİŞ}

Günümüzün yoğun rekabet ortamında işletmeler satış promosyonlarını daha yoğun ve etkili bir şekilde kullanmaya çalışmaktadırlar. Bu çaba, planlı alışverişlerin yanı sıra tüketicileri plansız satın alma davranışlarına da yöneltebilmektedir. Ancak tüketiciler bazen işletmelerin satış promosyonlarından etkilenip yaptıkları alışverişlerinin sonucunda pişmanlık duygusu yaşayabilmektedir. Türkçe literatürde plansız satın alma kavramı çeşitli çalışmalarda itkisel satın alma, dürtüsel satın alma, anlık veya ani satın alma şeklinde kullanılmaktadır. Bu çalışmada ise plansız satın alma kavramının kullanılması tercih edilmiştir. Plansız satın alma davranışı konusu ilk ele alındığı yıllarda, tüketicilerin alışveriş listesinde yer almayan ürünleri satın alması olarak ifade edilmiştir (Clover, 1951; Stern, 1962). Ancak daha sonra konunun kapsamı genişlemiş ve plansız satın alma davranışı psikolojik açıdan da değerlendirilerek tüketicilerin ruh hali, duygu durumu, kişisel özellikleri gibi içsel unsurlara dayalı olarak da ele alınmaya başlanmıştır (Rook, 1987; Rook ve Hoch, 1985).

Plansız satın alma farklı yazarlar tarafından zaman içerisinde farklı şekillerde ifade edilmiştir. Örneğin Stern (1962) plansız satın almayı, müşterinin alışveriş öncesinde plan yapmadan gerçekleştirdiği satın alma olarak dört alt boyutta ele almıştır. Plansız satın almaya ilişkin bu boyutlar; tamamen plansız satın alma, hatırlatıcı plansız satın alma, öneriyle yapılan plansız satın alma ve planlanmış plansız satın alma şeklinde belirtilebilir. Tamamen plansız satın alma, plan yapılmadan gerçekleşen satın alma türüdür. Hatırlatıcı plansız satın alma, tüketicinin alışveriş esnasında karşılaştığı ürün veya hizmete ilişkin ikna ve teşvik edici bilgi ve reklamların sunulmasıyla birlikte alınan satın alma kararıdır. Öneriyle yapılan plansız satın alma ise tüketicinin ürün/hizmetle karşılaştığında daha önce bilgisi olmadığı halde ürüne ihtiyacı olduğunu hissetmesi sonucunda gerçekleşen satın almadır. Planlanmış plansız satın alma ise tüketicinin planlı satın alma davranışı esnasında uygun fiyat, uygun promosyon gibi etkenleri değerlendirerek yaptığı satın almadır. Rook ve Hoch (1985) ise psikolojik açıdan ele aldığı plansız satın alma davranışının ani ve kendiliğinden ortaya çıktığını, satın alma için duyulan ani dürtünün tüketicide geçici de olsa psikolojik bir dengesizlik yarattığını ifade etmektedir. Bu dengesizlik sonucunda ise tüketicinin bilişsel değerlendirmesinin azaldığı için plansız satın alma gerçekleşmektedir. Rook (1987) sonraki çalışmasında tüketicinin ürünü hemen satın almak için ani ve güçlü bir dürtü duyduğunu ve bu dürtünün ise plansız satın alma davranışına neden olduğunu ifade etmektedir.

Tüketicilerin plansız satın alma davranışı üzerinde birçok faktör etkili olabilmektedir. Bu faktörler; "dışsal faktörler" (Mohan vd., 2013; Rasheed vd., 2017; Tinne, 2011), "içsel faktörler" (Rook ve Gardner, 1993; Beatty ve Ferrell, 1998), "tüketicilere ilişkin durumsal faktörler" (Virvilaite vd., 2009; Husnain vd., 2019) ve "tüketicilere ilişkin demografik özellikler" (Awan ve Abbas, 2015; Ekeng vd., 2012) şeklinde kategorize edilebilir. Literatürde mağaza ortamı, ürün özellikleri, satış promosyonları, mağaza personeli gibi faktörler plansız satın alma davranışını etkileyen dışsal faktörler olarak ifade edilmektedir.

Çalışmada satış promosyonları ve kredi kartı kullanım olanağı dışsal faktörler olarak ele alınmaktadır. Çalışmanın amacı, satış promosyonları ve tüketicilerin nakitleri olmasa da kredi kartıyla alışveriş yapabilmelerinin tüketicilerin plansız satın alma davranışlarına ve satın alma sonrasında pişmanlık davranışlarına etkisini ortaya koymaktır. Ayrıca oluşturulan model çerçevesinde plansız satın almanın aracı değişken, cinsiyetin de düzenleyici değişken olarak etkisi araştırılmıştır. Çalışma devamında ilk olarak plansız satın alma davranışları ve satın alma sonrasında pişmanlık davranışlarıyla ilgili literatür ele alınmıştır. İlgili literatür çerçevesinde de araştırma hipotezleri ve araştırma modeli oluşturulmuştur. Devamında araştırma metodolojisi ifade edilerek, araştırma verilerinin analizi sonucunda bulunan demografik veriler, ölçüm modeli analiz sonuçları ile araştırma modelinin yapısal eşitlik modeli analiz sonuçları verilmiştir. Çalışmanın sonuç bölümünde ise araştırma bulguları, ilgili literatür ile karşılaştırılarak hem teorik hem pratik açıdan değerlendirilerek gelecekteki araştırmalar için öneriler sunulmuştur.

\section{LITERATÜR TARAMASI}

\subsection{Plansız Satın Alma Davranışı}

İlgili literatür incelendiğinde plansız satın alma davranışı konusunda çeşitli çalışmaların (Tinne, 2011; Virvilaitè vd., 2011; Saleh, 2012; Ozer ve Gultekin, 2015; Lim vd., 2017; Husnain vd., 2019) olduğu görülmektedir. Bu çalışmaların bir kısmı plansız satın almayı etkileyen dışsal faktörlere odaklanmıştır. Örneğin plansız satın alma konusunda Karbasivar ve Yarahmadi (2011) İran'da yaptıkları çalışmada vitrin 


\section{E. Özdemir - S. K1lıç - M. A. Çakırer 11/4 (2019) 2528-2545}

düzenlemesi, kredi kartı kullanımı, nakit indirimi ve ücretsiz ürün verme gibi promosyonel faaliyetlerin plansız satın alma davranışı üzerindeki etkilerini araştırmışlardır. Araştırma sonucunda tüm bu promosyonel faaliyetlerin plansız satın alma davranışı üzerinde etkili olduğu, en fazla etkinin ise vitrin düzenlemesiyle sağlandığı bulunmuştur. Tinne (2011) ise çalışmasında indirim teklifi, tanıtım faaliyetleri, mağaza sunumu, ürün gösterimi, satış elemanlarının davranışları, ürün markası, referans grubunun etkisi, müşterilerin gelir düzeyi ve festival zamanları gibi çeşitli değişkenlerin tüketicilerin plansız satın alma davranışı üzerindeki etkilerini araştırmıştır. Plansız satın almada etkili olan zaman, yaş, cinsiyet, ruh hali, materyalizm, kültür, mağaza atmosferi, satış elemanları, mağaza türü, ürün kategorisi ve fiyatları, alışveriş keyfi, başkalarının varlığı gibi unsurlar da çalışmada değerlendirilmiştir. Çalışma sonucunda fiyatlandırma stratejileri, mağaza özellikleri, durumsal faktörler ve tanıtım faaliyetlerinin plansız satın almayı büyük ölçüde etkileyen faktörler olduğu bulunmuştur. Ayrıca ürünün markası, referans grupların yorumları ve festival zamanlarındaki ürünlerin gerekliliği gibi durumsal faktörlerin de plansız satın almayı etkilediği bulunmuştur. Kişisel ve mağaza içi faktörlerin plansız satın alma üzerindeki etkilerini $Y$ kuşağındaki bireyler üzerinde araştıran Husnain ve arkadaşları (2019) ise araştırmaları sonucunda zaman ve aile gibi kişisel faktörler ile mağaza içi faktörlerin plansız satın alma davranışı üzerinde etkili olduğunu bulmuşlardır. Bir diğer çalışmada Mihić ve Kursan (2010) durumsal faktörlerin plansız satın alma üzerindeki etkilerini araştırarak tüketicileri bölümlere ayırmışlardır. Bu araştırma sonucuna göre tüketiciler (1) belirgin derecede rasyonel, (2) bir dereceye kadar etkileyici (bazı durumsal uyaranlara duyarlı), (3) çoğunlukla rasyonel şeklinde üç gruba ayrılmaktadır.

Literatürde yer alan bazı çalışmalarda ise plansız satın alma davranışı etkileyen psikolojik faktörlere odaklanılmıştır. Eren ve arkadaşları (2012) plansız satın alma davranışını, materyalistik ve hedonik değerlerin bir sonucu olarak ifade etmişlerdir. Türkiye'deki farklı üniversitelerde öğrenim gören öğrenciler üzerinde yaptıkları araştırmaları sonucunda hedonizm ve materyalizmin plansız satın alma davranışı üzerinde önemli ve doğrudan etkilerinin olduğunu bulmuşlardır. Plansız satın alma eğiliminin ve satın alma öncesi ruh halinin plansız satın alma davranışı üzerindeki etkilerini araştıran Ozer ve Gultekin (2015) ise, çalışmalarında bu iki faktörün de plansız satın alma davranışı üzerinde pozitif etkiye sahip olduğunu bulmuşlardır. Virvilaitè ve arkadaşları (2011) duygusal ve bilişsel tahmin, hedonik güdüler ve modaya katılım gibi içsel uyaranlar ile mağaza çevresi, mağaza çalışanı ve bütünleşik pazarlama iletişimi gibi dışsal uyaranların tüketicilerin plansız satın almalarını etkilediğini bulmuşlardır. Saleh (2012) de çalışmasında kredi kartı kullanımının para gerekliliğini azalttığını ve bunun da plansız satın alma olasılığını arttırdığını belirtmektedir.

\subsection{Satın Alma Sonrası Pişmanlık Davranışı}

Satın alma sonrası pişmanlık davranışı literatürde plansız satın alma davranışı dışındaki konularla da çalışılmıştır. Lee ve Cotte (2009) çalışmalarında, tüketicilerin satın alma işlemleriyle ilgili olarak süreçten ve sonuçtan duydukları pişmanlığı ele alarak, satın alma sonrası pişmanlık ölçeğini geliştirmişlerdir. Buchanan ve arkadaşları (2016) ise çalışmalarında pişmanlık ölçeğindeki bilişsel ve duyusal unsurları ayırt etmişlerdir. M'Barek ve Gharbi (2011) ise satın alma sonrası pişmanlık deneyimini etkileyen faktörleri durumsal ve bireysel aracı faktörler olarak ele almışlar ve araştırmalarını derinlemesine görüşme ve odak grup görüşmeleriyle gerçekleştirmişlerdir.

Pişmanlık konusunda yapılan çalışmaların önemli bir kısmı ise pişmanlık davranışını etkileyen faktörler ve pişmanlık davranışının sonuçlarına ilişkin tepkileri ele almaktadır. Chang ve arkadaşları (2015) ürün pişmanlığının, tüketicilerin tekrar satın alma niyeti üzerindeki etkisini ve tüketicilerin güç durumunun pişmanlık ve ürün nitelikleri arasındaki aracılık ilişkisini araştırdıkları çalışmalarının sonucunda ürün pişmanlığının tekrar satın alma niyetini negatif etkilediğini bulmuştur. Moakhar ve arkadaşları (2018) ise pişmanlık aracı değişkenlerinin tüketicilerin satın alma sonrası davranışları üzerindeki etkilerini araştırmışlardır. Çalışma sonucunda algılanan sorumluluk, seçenek sayısı, benlik, sosyal karşılaştırma, karamsarlığa karşı iyimserliğin ve mükemmeliyetçilik faktörlerinin satın alma sonrası pişmanlık üzerinde etkilerinin olduğu bulunmuştur. Clarke ve Mortimer (2013) de tüketicilerdeki kendine hediye satın alma ile satın alma sonrası pişmanlık arasındaki ilişkiyi incelemişlerdir. Araștırma sonuçlarına göre, farklı müşteriler farklı nedenlerle kendilerine hediye almakta ve kendi kendine hediye motivasyonlarının tümü pişmanlık oluşturmamaktadır.

Pişmanlığın nedenlerini ve pişmanlığın giderilmesinde tüketicilerin tepkilerini ele aldıkları çalışmalarında Akçi ve Kılınç (2016) ise tüketicilerin pişmanlık sonucunda en çok gösterdikleri tepkilerin ilgili mağazadan 


\section{E. Özdemir - S. K1lıç - M. A. Çakırer 11/4 (2019) 2528-2545}

alışveriş yapmayı bırakmak ve çevreye yaşanan olumsuzlukları paylaşmak olduğunu ifade etmişlerdir. Tüketicilerin özellikle alışveriş sonrasında fiyat indirimi olduğunu gördüklerinde pişman oldukları görülmüştür. Akbari ve Radmand (2016) çalışmalarında satın alma sonrası pişmanlığın satın almadan kaynaklanan olumsuz duyguları ve marka değiştirmeyi doğrudan etkilediğini ve tüketici tatmini üzerinde ters etkisinin olduğunu bulmuştur. Unal ve Aydın (2016), algılanan riskin pişmanlık üzerindeki etkisini ve pişmanlığın tekrar alım niyetine etkisini Türkiye'de yeni ve kullanılmış otomobil alıcıları üzerinde araştırmışlardır. Araştırma sonuçları yeni ve kullanılmış araba alıcılarında algılanan riskin pişmanlık üzerindeki etkisini ortaya koymaktadır. Buna göre finansal riskin, yeni araba alımlarından sonra pişmanlık üzerinde daha fazla etkisi vardır.

Literatürde yer alan bazı çalışmalarda ise pişmanlık konusu farklı konularla ilişkilendirilerek ele alınmıştır. Örneğin Kurt ve Bayraktaroğlu (2013) yaptıkları çalışmada pişmanlık düzeyi üzerinde hazcı ve faydacı ürünleri karşılaştırmışlar ve pişmanlık düzeyinin hazcı ürünlerde daha yüksek olduğu bulunmuştur. Akarsu ve Yeniaras (2014) ise çalışmalarında Müslüman dindarlığın plansız alışverişi ve alışveriş sonrası pişmanlık durumunu arttırdığını bulmuşlardır. Az sayıdaki çalışmada plansız satın alma, satın alma sonrası pişmanlık davranışı ile satış promosyonları ve kredi kartı kullanımı arasındaki ilişkiler ele alınmıştır. Örneğin Korur ve Kimzan (2016) çalışmalarında plansız satın alma davranışı ve kredi kartının kötüye kullanımının alışveriş sonrası pişmanlığa sebep olduğunu ortaya koymuşlardır. Plansız satın almanın tüketici kültürü ve satın alma sonrası pişmanlıkla ilişkisini öğrenciler üzerinde araştıran Bushra ve Bilal (2014) ise araştırmaları sonucunda satış promosyonlarının planlanmamış satın alma ve satın alma sonrası pişmanlıkla ilişkisinin ve banka kartı ödemelerinin de planlanmamış satın almayla doğrudan bir ilişkisinin olmadığını bulmuşlardır. Bushra (2015) ise çalışmasında statü tüketiminin plansız satın alma ile pişmanlık sonrası davranış üzerinde güçlü bir etkiye sahip olduğunu bulmuştur. Araştırma sonucunda ayrıca materyalizm ile plansız satın alma arasında pozitif bir ilişkinin olduğu; banka kartı ödemesinin ise planlanmamış satın alma ile doğrudan bir ilişkisinin olmadığı bulunmuştur. Bu çalışmada satış promosyonlarının plansız satın alma ve satın alma sonrası pişmanlık üzerinde etkisi ise bulunmamıştır. Handayani ve arkadaşları (2018) ise kadın tüketiciler üzerinde gerçekleştirdikleri çalışmalarında plansız satın alma ile bireylerin mutluluğuna etki eden faktörleri araştırmışlardır. Araştırma sonucunda alışverișten zevk almanın ve hoș alışveriş atmosferinin plansız satın almayı etkilediği, bunun sonucunda ise plansız satın almanın mutluluğa etkisinin olduğu bulunmuştur.

\subsection{Plansız Satın Alma Davranışı ve Cinsiyet İlişkisi}

Plansız satın alma konusunun ilişkilendirildiği alanlardan biri de cinsiyettir. Çalışmalarda plansız satın almanın kadın ve erkek tüketicilerde farklılıkları ele alınmaktadır. Bu tür çalışmalardan birinde Coley ve Burgess (2003), plansız satın almada bilişsel ve duyusal süreç unsurları ile plansız satın alınan ürün kategorileri arasındaki farklılıkları cinsiyet açısından araştırmışlardır. Araştırma sonucunda kadınların bilişsel ve duyusal olarak daha fazla plansız davrandıkları bulunmuştur. Torlak ve arkadaşları (2013) ise çalışmalarında algılanan zaman baskısının plansız satın alma eğilimi üzerindeki etkisini üniversite öğrencileri üzerinde araştırmışlardır. Araştırma sonucunda algılanan zaman baskısının plansız satın alma eğilimi üzerinde pozitif bir etkiye sahip olduğu, erkek öğrencilere göre kız öğrencilerin algıladıkları zaman baskısının ve plansız satın alma eğilimlerinin daha yüksek olduğu bulunmuştur. Muratore (2016) ise çalışmasında plansız satın alma ile fiyatın pozitif (prestij duyarlılığı, fiyat kalite şeması) (ürünün kalitesiyle fiyatın uyumluluğu) ve negatif (fiyat bilinci, değer bilinci, fiyat mavenizmi (bireyin pazar kurdu olma derecesi), satış eğilimi) ilişkisini araştırmıştır. Genç tüketiciler üzerinde gerçekleştirilen araştırma sonucunda plansız satın alma yapmayanlara göre plansız satın alma yapanlar daha fazla prestij duyarlılı̆̆ına, fiyat-kalite ilişkisine, fiyat kurdu olmaya (mavenizm), satış eğilimlerine ve daha düşük fiyat ve değer bilincine sahiplerdir. Ayrıca çalışma sonucunda erkeklere göre kadınların daha fazla plansız satın alma yapmaya eğilimli oldukları bulunmuştur.

\subsection{Satın Alma Sonrası Pişmanlık Davranışı ve Cinsiyet İlişkisi}

Plansız satın alma davranışlarında cinsiyet farklılıklarını incelediği çalışmasında Imam (2013) kadın tüketicilerin plansız satın alma sonrası daha fazla alım sonrası uyumsuzluk yaşadıklarını ifade etmektedir. Plansız satın alma sonrasında memnuniyetsizlik oluştuğunda pişmanlıklara dönüşen yoğun olumsuz duygusal tepkiler ortaya çıkmaktadır. Wulandari (2016) ise cinsiyet değişkenini düzenleyici değişken olarak kullandığı çalışmasında, plansız satın almanın satın alma sonrası pişmanlığa ve satış promosyonunun ve 


\section{E. Özdemir - S. Kılıç - M. A. Çakırer 11/4 (2019) 2528-2545}

görsel tanzim-teşhirin plansız satın almaya etkisini araştırmıştır. Çalışma sonucunda, plansız satın almanın satın alma sonrası pişmanlık üzerinde pozitif bir etkisinin olduğu bulunmuştur. Düzenleyici değişken olarak cinsiyetin ele alındığı bu çalışmada, Kadın tüketiciler arasında planlanmamış satın alma sonrası satın alma pişmanlığı ile pozitif bir ilişki varken; erkek tüketiciler arasında bulunmamıştır. Ayrıca satış promosyonunun plansız satın alma üzerinde pozitif etkisi de bulunmuştur. Erkek tüketicilerin plansız satın alma üzerindeki etkisi de kadınlardan daha fazladır. Plansız satın alma ve satın alma sonrası pişmanlık arasındaki ilişkiyi ve bu ilişkiye etki eden unsurları araştırdığı çalışmasında Saleh (2012), satış promosyonlarına göre kredi kartı kullanımının plansız satın alma üzerinde daha fazla etkiye sahip olduğunu; kadınlara göre erkeklerin plansız satın alımdan sonra daha fazla satın alma sonrası pişmanlık yaşadıklarını bulmuştur. Ayrıca satış promosyonunun plansız satın alma ile doğrudan bir ilişkisi ve satın alma sonrası pişmanlık ile önemli bir ilişkisinin olmadığı ortaya konulmuştur.

Yukarıda ele alınan literatür taraması sonucunda araştırmanın amacına uygun olarak oluşturulan hipotezler aşağıda verilmiş ve araştırma modeli şekil 1'de gösterilmiştir.

Hı: Satış promosyonları plansız satın alma davranışı üzerinde pozitif bir etkiye sahiptir.

$\mathbf{H}_{2}$ : Kredi kartıyla satın alabilme plansız satın alma davranışı üzerinde pozitif bir etkiye sahiptir.

$\mathbf{H}_{3}$ : Satış promosyonları, satın alma sonrası pişmanlık davranışı üzerinde pozitif bir etkiye sahiptir.

H4: Kredi kartıyla satın alabilme, satın alma sonrası pişmanlık davranışı üzerinde pozitif bir etkiye sahiptir.

H5: Plansız satın alma davranışı, satın alma sonrası pişmanlık davranışı üzerinde pozitif bir etkiye sahiptir.

Yukarıda belirlenen hipotezlerin dışında ayrıca satış promosyonları ve kredi kartıyla satın alabilme boyutlarının aracı değişken olarak plansız satın alma davranışı üzerinden satın alma sonrası pişmanlık davranışına etkisi de araştırılmak istenmiştir. Bu amaç doğrultusunda belirlenen hipotezler ise şunlardır:

H6: Plansız satın alma davranışı, satış promosyonları ile satın alma sonrası pişmanlık davranışını arasında aracilık etkisine sahiptir.

H7: Plansız satın alma davranışı, kredi kartıyla satın alabilme ile satın alma sonrası pişmanlık davranışı arasında aracılık etkisine sahiptir.

Çalışmanın devamında cinsiyetin modeldeki düzenleyici rolü de araştırılmaktadır. Bu amaçla oluşturulan sekizinci hipotezin alt hipotezleri şunlardır:

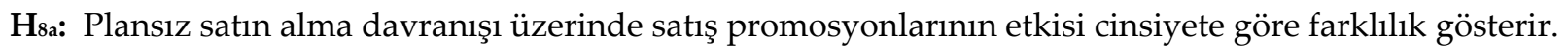

$H_{8 b}$ : Plansız satın alma davranışı üzerinde kredi kartıyla satın alabilmenin etkisi cinsiyete göre farklılık gösterir.

Hsc: Plansız satın alma davranışının satın alma sonrası pişmanlık davranışı üzerindeki erkek cinsiyete göre farklılık gösterir.

$H_{8 d:}$ Satın alma sonrası pişmanlık davranışı üzerinde satış promosyonlarının etkisi cinsiyete göre farklılık gösterir.

Hse: Satın alma sonrası pişmanlık davranışı üzerinde kredi kartıyla satın alabilmenin etkisi cinsiyete göre farklılık gösterir.

Yukarıda ifade edilen hipotezler çerçevesinde oluşturulan araştırma modeli aşağıdaki Şekil 1'de görülmektedir. 


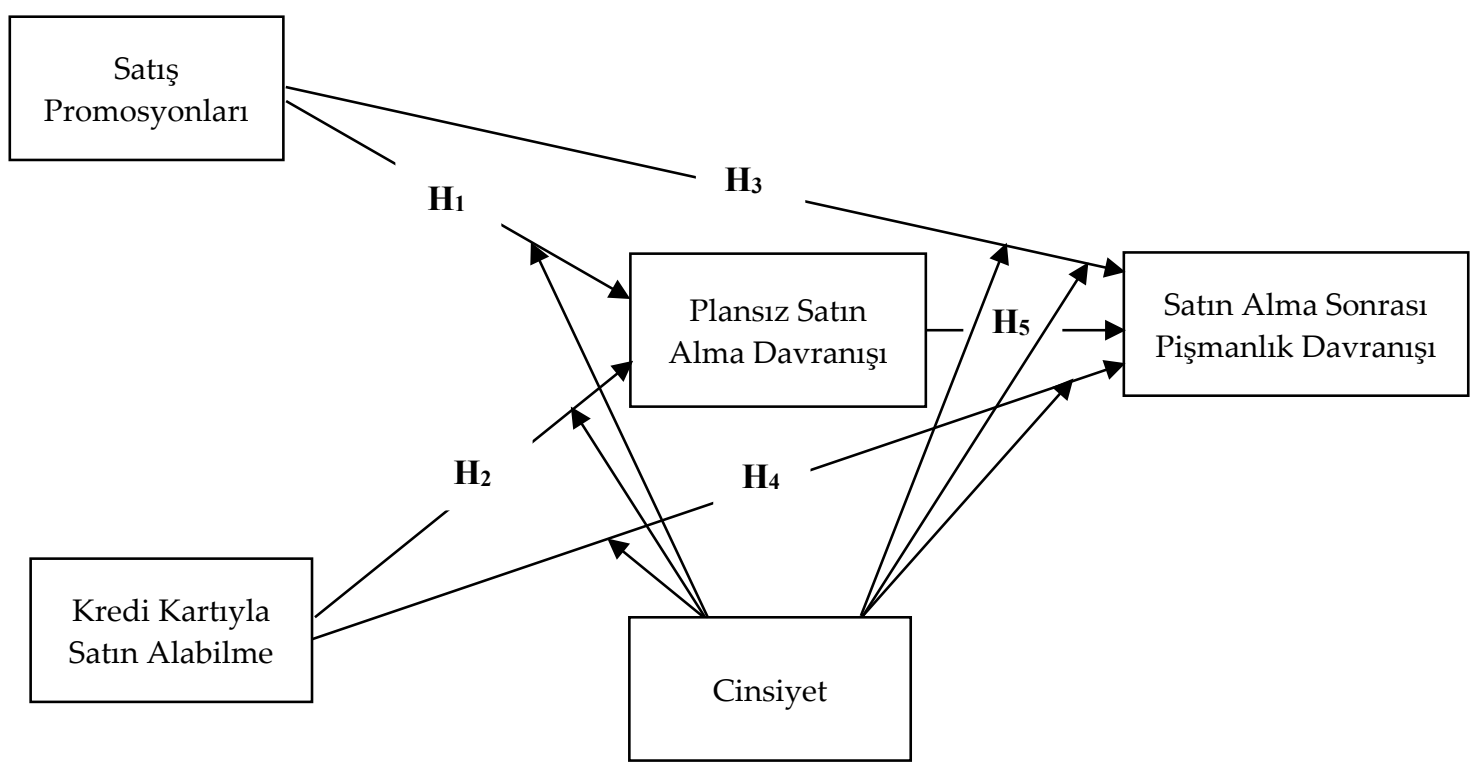

Şekil 1. Araştırma Modeli

\section{YÖNTEM}

Araştırmanın amacı, satış promosyonları ve tüketicilerin kredi kartıyla alışveriş yapabilmelerinin plansız satın alma ve satın alma sonrasında pişmanlık davranışları üzerindeki etkilerini ortaya koymaktır. Ayrıca oluşturulan model çerçevesinde plansız satın almanın aracı değişken, cinsiyetin de düzenleyici değişken olarak etkilerinin ortaya konulması da amaçlanmaktadır. Araştırma verileri, Afyonkarahisar'da yaşayan kişilerden yüz yüze anket yöntemiyle toplanmıştır. Araştırmada, kolayda örnekleme yöntemi kullanılmıştır. Araştırma için ulaşılması gereken örneklem büyüklüğü belirlenirken, Sekaran (2003: 294) tarafından belirtilen ana kütleye göre belirlenen maksimum örneklem büyüklüğü sayısı (minimum 384 kişi) dikkate alınmıştır. Anket formunda yer alan soruların anlaşılırlığını test etmek ve eksiklikleri belirlemek için öncelikle bir pilot çalışma yapılmıştır. Pilot çalışma, 1 - 10 Şubat 2018 tarihleri arasında araştırmanın hedef kitlesi içerisinde yer alan 30 kişi üzerinde gerçekleştirilmiştir. Yüz yüze anket yönteminin kullanıldığı bu pilot çalışma sonucunda anket formundaki ifadeler üzerinde bazı küçük düzeltmeler yapılmış ancak herhangi bir ifade anketten çıkarılmamıştır. Pilot çalışmanın devamında araştırma 1 Nisan 2018 ve 21 Mayıs 2018 arasında gerçekleştirilmiştir. Maliyet ve zaman kısıtları göz önüne alınarak örneklem yöntemi olarak kolayda örneklem kullanılmıştır. Veri toplama süreci sonucunda 460 anket toplanmıştır. Ancak 57 adet anket formunda eksik eksiklikler ve hatalardan dolayı analize dâhil edilmemiştir. Dolayısıyla 403 anket analizlerde kullanılmıştır. Veri analizinde IBM SPSS 23 ve Smart PLS 3.2.8 paket programları kullanılmıştır.

Anket formunda "kategorik sorular" ve "Likert ölçek soruları" olmak üzere iki bölüm bulunmaktadır. Anket formunun ilk bölümünde kredi kartıyla satın alabilmeye ilişkin sorular ( 8 soru), plansız satın alma davranışına ilişkin sorular (9 soru), satın alma sonrası pişmanlık davranışına ilişkin sorular (4 soru), satış promosyonlarına ilişkin sorular (6 soru), toplam 27 soru Saleh'in (2012) çalışmasında kullandığı ölçek sorularından yararlanılarak oluşturulmuştur. Ölçek soruları 5'li likert ölçeği (1=Kesinlikle Katılmıyorum, 2=Katılmıyorum, 3=Kararsızım, 4=Katılıyorum, 5=Kesinlikle Katıllyorum) kullanılarak değerlendirilmiştir. Anket formunun ikinci bölümünde ise katılımcıların özelliklerine ilişkin kategorik sorular bulunmaktadır. 


\section{BULGULAR}

Verilerinin analizinde ilk olarak katılımcıların demografik özelliklerini belirlemek için frekans analizi yapılmıştır. Daha sonrada analizlerde kullanılan ölçek boyutlarının güvenilirlik ve geçerlilikleri analiz edilmiş ve sonrasında önerilen araştırma modeli Smart PLS 3.2.8 kullanılarak test edilmiştir.

\subsection{Cevaplayıcılara İlişkin Bulgular}

Araştırmaya katılan cevaplayıcıların demografik özelliklerine ilişkin veriler aşağıdaki Tablo 1'de görülmektedir.

Tablo 1. Cevaplayıcıların Demografik Özellikleri

\begin{tabular}{|c|c|c|c|c|c|c|c|}
\hline \multicolumn{2}{|c|}{ Özellik } & \multirow{2}{*}{$\frac{\mathbf{f}}{176}$} & \multirow{2}{*}{$\frac{\%}{43,7}$} & \multicolumn{2}{|r|}{ Özellik } & $\mathbf{f}$ & $\%$ \\
\hline \multirow{2}{*}{ Cinsiyet } & Kadın & & & \multirow{7}{*}{$\begin{array}{l}\text { Gelir } \\
\text { Düzeyi }\end{array}$} & 1000 TL ve altı & 136 & 33,7 \\
\hline & Erkek & 227 & 56,3 & & $1001 \mathrm{TL}-2000 \mathrm{TL}$ & 121 & 30 \\
\hline \multirow{5}{*}{ Yaş } & $15-24$ yaş arası & 154 & 38,2 & & $2001 \mathrm{TL}-3000 \mathrm{TL}$ & 77 & 19,1 \\
\hline & 25-34 yaş arası & 119 & 29,5 & & $3001 \mathrm{TL}-4000 \mathrm{TL}$ & 28 & 6,9 \\
\hline & 35-44 yaş arası & 85 & 21,1 & & $4001 \mathrm{TL}-5000 \mathrm{TL}$ & 19 & 4,7 \\
\hline & 45-54 yaş arası & 34 & 8,4 & & $5001 \mathrm{TL}-6000 \mathrm{TL}$ & 14 & 3,5 \\
\hline & 55 ve üzeri yaş & 11 & 2,7 & & 6001 TL ve üzeri & 8 & 1,9 \\
\hline \multirow{7}{*}{$\begin{array}{l}\text { Eğitim } \\
\text { Durumu }\end{array}$} & İlkokul & 18 & 4,5 & \multirow{7}{*}{ Meslek } & Kamu Çalışanı & 61 & 15,1 \\
\hline & Ortaokul & 56 & 13,9 & & Özel Sektör Çalışanı & 128 & 31,8 \\
\hline & Lise & 116 & 28,8 & & İşveren & 35 & 8,7 \\
\hline & Ön Lisans & 109 & 27 & & Emekli & 10 & 2,5 \\
\hline & Lisans & 88 & 21,8 & & İşsiz & 21 & 5,2 \\
\hline & Lisans & 15 & 3,7 & & Öğrenci & 137 & 34 \\
\hline & Doktora & 1 & 0,2 & & Diğer & 11 & 2,7 \\
\hline \multirow{2}{*}{$\begin{array}{l}\text { Medeni } \\
\text { Durum }\end{array}$} & Bekâr & 261 & 64,8 & \multirow{4}{*}{$\begin{array}{l}\text { Sahip } \\
\text { Olunan } \\
\text { Kredi } \\
\text { Kartı Sayısı }\end{array}$} & 1 adet & 189 & 46,9 \\
\hline & Evli & 142 & 35,2 & & 2 adet & 113 & 28 \\
\hline & & & & & 3 adet & 77 & 19,1 \\
\hline & & & & & 4 adet ve üzeri & 24 & 6 \\
\hline
\end{tabular}

Tablo 1'de görüldüğü üzere, ankete katılanların çoğunluğun erkek ve 15-35 yaş aralığında olduğu görülmektedir. Bekâr olanların oranı evli olanlara göre daha fazladır. Katılımcıların çoğunluğu lise ve ön lisans mezunlarından oluşmaktadır. Ayrıca katılımcıların yaklaşık \%83'ü 3000 TL'nin altında gelire sahiptir. Araştırmaya en çok katılan meslek grubunu sırasıyla öğrenciler, özel sektör çalışanları ve kamu çalışanları oluşturmaktadır. Araştırmada ayrıca kategorik sorular içinde katılımcılara kaç adet kredi kartına sahip oldukları da sorulmuştur. Cevaplayıcıların önemli bir kısmı (yaklaşık \% 47'si) bir adet kredi kartına sahip olduğunu belirtmiştir. Yüzde 47'lik bir oran ise 2-3 kredi kartına sahip olduğunu ifade etmiştir.

\section{2. Ölçüm Modeli Analiz Sonuçlanı}

Araştırma modelinin test edilmesinde yapısal eşitlik modellemesi kullanılmıştır. Yapısal eşitlik modellemesi pazarlama alanında oldukça popüler olan bir istatistik tekniğidir (Henseler, 2017: 361). Bu çalışmada yapısal eşitlik modellemesi tekniklerinden araştırma modelinin test edilmesinde varyans bazlı yapısal eşitlik modelleme tekniği olarak PLS SEM kullanılmıştır. Bu teknik, kovaryans bazlı SEM tekniklerine göre parametrik olmayan yapısı (normal dağılımı gerektirmemesi), karmaşık modelleri ele alabilmesi, istatistiki gücü, küçük örneklemlerle çalışabilmesi ve uyum iyiliği değerlerini gerektirmemesi gibi özelliklere sahiptir (Sarstedt vd., 2017: 11-14). Bu çalışmada yeterli örneklem büyüklüğüne ulaşılmıştır. Ancak PLS SEM tekniği normal dağılım gerektirmediği için tercih edilmiştir. Ölçek boyutlarının güvenilirlik ve geçerlilik analizleri ve sonrasında önerilen araştırma modelinin testi Smart PLS 3.2.8 paket programı kullanılarak yapılmıştır. 


\section{E. Özdemir - S. Kılıç - M. A. Çakırer 11/4 (2019) 2528-2545}

Araştırmada yer alan boyutların geçerlilik ve güvenilirlik analizi kapsamında verilerin iç tutarlılık güvenilirliği, birleşme geçerliliği ve ayrışma geçerliliği analizleri yapılmıştır. Güvenilirlik (Cronbach's Alfa) ve birleşik güvenilirlik (Composite Reliability/CR) değerleri hesaplanmıştır. Faktör yükleriyle açılanan ortalama varyans (AVE=Average Variance Extracted) değerleri birleşme geçerliliğinin analizi için kullanılmıştır. Cronbach's Alfa ve CR değerleri ölçeğin içerdiği maddelerin birbiriyle ne ölçüde tutarlı olduğunu ölçmek için kullanılırken, AVE değeri gizil yapıyı temsil eden belirli ifadeler arasındaki yakınlaşmanın ölçüsünü görmek için kullanılmaktadır. Hair ve arkadaşlarına (2014: 618-619) göre faktör yükleri 0,50'nin üzerinde, Cronbach's Alpha ve Birleşik Güvenirlik (CR) değerleri 0,70'in üzerinde ve Açıklanan Ortalama Varyans (AVE) değeri de 0,50'nin üzerinde olmalıdır. Bu araştırmada kullanılan ölçekte 27 ifade değerlendirilmiş olup, ölçeğin genel güvenilirliğine ilişkin Cronbach's Alfa katsayısı 0,869 bulunmuştur. $\mathrm{Bu}$ sonuç literatürde kabul edilen 0,70 değerinin üzerinde olduğundan ölçeğin genel güvenilirliğinin yüksek olduğu ifade edilebilir. Aşağıdaki tablo 2'de araştırma modelinde yer alan boyutların ölçüm modeli analiz sonuçları görülmektedir.

Tablo 2 incelendiğinde, 27 ifadeyle başlanılan analiz sonucunda eşik değerlerin üzerinde güvenilirlik ve geçerlilik değerlerinin elde edilmesi için faktör yükleri düşük olan 12 ifade analizlerden çıkarılmıştır. Çünkü Hair ve arkadaşları (2014: 618) çalışmalarında faktör yükünün 0,50'nin üzerinde olmasını, ideal olarak ise 0,70 değerini aşması gerektiğini ifade etmektedirler. Bu nedenle güvenilirlik ve geçerlilik için istenen değerleri elde etmek için öncelikle 0,50 değerinin altında faktör yüküne sahip olan ifadeler, sonrasında ise eşik değeri düşüren ifadeler analizden çıkarılmıştır. Analizden çıkarılan ifadelerin kodları şunlardır: SP1, SP5, SP6, KKSA1, KKSA7, KKSA8, PSA1, PSA4, PSA5, PSA6, PSA8, SASPD4. Bu ifadeler analizden çıarılınca yapıların faktör yükleri 0,631 ile 0,854 arasında bulunmuştur. Analizden çıkarılan ifadeler sonucunda boyutların AVE değerleri ise 0,517 ile 0,633 arasında bulunmuştur. Bu değerler birleşme geçerliliğinin sağlandığını göstermektedir. Bu değerler kabul edilebilir bir eşik değer olan 0,50'nin üzerindedir. Elde edilen değerler, ortalama olarak, içeriğindeki ifadelerin varyansının \%50'sinden fazlasını açıkladığını göstermektedir (Sarstedt vd., 2017: 17). 
E. Özdemir - S. Kılıç - M. A. Çakırer 11/4 (2019) 2528-2545

Tablo 2. Ölçüm Modeli Analiz Sonuçları

\begin{tabular}{|c|c|c|c|c|c|c|}
\hline Değişken & İfade & $\begin{array}{l}\text { İfade } \\
\text { Kodu }\end{array}$ & $\begin{array}{r}\text { Faktör } \\
\text { Yükü }\end{array}$ & $\begin{array}{l}\text { Cronbach's } \\
\text { Alpha }\end{array}$ & $\begin{array}{l}\text { Birleşik } \\
\text { Güvenirlik } \\
\quad \text { (CR) }\end{array}$ & $\begin{array}{l}\text { Açıllanan } \\
\text { Ortalama } \\
\text { Varyans } \\
\text { (AVE) }\end{array}$ \\
\hline \multirow{3}{*}{$\begin{array}{c}\text { Satış } \\
\text { Promos- } \\
\text { yonları (SP) }\end{array}$} & $\begin{array}{l}\text { Ziyaret ettiğim mağazalar her zaman } \\
\text { bazı ürünlerden ücretsiz numuneler } \\
\text { verir. }\end{array}$ & SP2 & 0,819 & \multirow{3}{*}{0,717} & \multirow{3}{*}{0,837} & \multirow{3}{*}{0,633} \\
\hline & $\begin{array}{l}\text { Mağazaları ziyaret ederken, belirli bir } \\
\text { satın alma değerini aşanlara yönelik } \\
\text { yarışmaları her zaman bulurum. }\end{array}$ & SP3 & 0,854 & & & \\
\hline & $\begin{array}{l}\text { Mağazalar, her zaman belirli bir satın } \\
\text { miktarını aşanlara promosyon verir. }\end{array}$ & SP4 & 0,705 & & & \\
\hline \multirow{5}{*}{$\begin{array}{l}\text { Kredi } \\
\text { Kartıyla } \\
\text { Satın } \\
\text { Alabilme } \\
\text { (KKSA) }\end{array}$} & $\begin{array}{l}\text { Mağazada bazı ürünleri gördüğümde, } \\
\text { gerçekten ihtiyacım olup olmadığını } \\
\text { düşünmeden bu ürünleri satın alırım. }\end{array}$ & KKSA2 & 0,710 & \multirow{5}{*}{0,769} & \multirow{5}{*}{0,843} & \multirow{5}{*}{0,517} \\
\hline & $\begin{array}{l}\text { Perakende satış mağazalarından } \\
\text { yaptığım alışverişler için genellikle } \\
\text { kredi kartlarımı kullanırım. }\end{array}$ & KKSA3 & 0,702 & & & \\
\hline & $\begin{array}{l}\text { Satın alma sürecinde kredi kartı } \\
\text { kullanırken, ürün fiyatına daha az } \\
\text { duyarlı olurum. }\end{array}$ & KKSA4 & 0,732 & & & \\
\hline & $\begin{array}{l}\text { Kredi kartımı kullanabilmek, beni } \\
\text { alışveriş için perakende mağazaları } \\
\text { tekrar ziyaret etmeye teşvik eder. }\end{array}$ & KKSA5 & 0,737 & & & \\
\hline & $\begin{array}{l}\text { Kredi kartımı kullanabilmek, } \\
\text { mağazalardan satın aldığım ürünlerin } \\
\text { değeri konusunda sınır koymamam } \\
\text { yönünde beni cesaretlendirir. }\end{array}$ & KKSA6 & 0,716 & & & \\
\hline \multirow{4}{*}{$\begin{array}{l}\text { Plansız } \\
\text { Satın Alma } \\
\text { Davranışı } \\
\text { (PSAD) }\end{array}$} & $\begin{array}{l}\text { Mağazada bir ürün gördüğümde, } \\
\text { gerçekten ihtiyacım olup olmadığını } \\
\text { düşünmeden hemen satın alırım. }\end{array}$ & PSA2 & 0,739 & \multirow{4}{*}{0,693} & \multirow{4}{*}{0,811} & \multirow{4}{*}{0,518} \\
\hline & $\begin{array}{l}\text { Mağazada bazı ürünleri satın almakta } \\
\text { tereddüt ettiğimde, "kendime şimdi al } \\
\text { ve sonra düşün" derim. }\end{array}$ & PSA3 & 0,774 & & & \\
\hline & $\begin{array}{l}\text { Genellikle, normalde satın almadığım } \\
\text { ürünleri satın alırım. }\end{array}$ & PSA7 & 0,631 & & & \\
\hline & $\begin{array}{l}\text { Çoğu zaman hiç kullanmadı̆̆ım } \\
\text { ürünleri de satın alırım. }\end{array}$ & PSA9 & 0,728 & & & \\
\hline \multirow{3}{*}{$\begin{array}{l}\text { Satın Alma } \\
\text { Sonrası } \\
\text { Pişmanlık } \\
\text { Davranışı } \\
\text { (SASPD) }\end{array}$} & $\begin{array}{l}\text { Mağazaya girmeden önce } \\
\text { planlamadığım ürünleri satın aldıktan } \\
\text { sonra kaygı hissederim }\end{array}$ & SASPD1 & 0,676 & \multirow{3}{*}{0,607} & \multirow{3}{*}{0,791} & \multirow{3}{*}{0,560} \\
\hline & $\begin{array}{l}\text { Planlanmamış satın alımlarımın çok } \\
\text { az yararının dahi olmadığını } \\
\text { hissederim. }\end{array}$ & SASPD2 & 0,835 & & & \\
\hline & $\begin{array}{l}\text { Çoğunlukla satın aldıklarımdan daha } \\
\text { sonra faydalanabileceğine kendimi } \\
\text { inandırmaya çalışırım. }\end{array}$ & SASPD3 & 0,725 & & & \\
\hline
\end{tabular}

Tablo 2 incelendiğinde, analizde kullanılan yapıların Cronbach's Alfa katsayılarının 0,607 ile 0,769 arasında olduğu görülmektedir. Plansız Satın Alma Davranışı (PSAD) ve Satın Alma Sonrası Pişmanlık Davranışı (SASPD) boyutlarının Cronbach's Alfa katsayıları 0,70 değerinin altında çımıştır. Ancak 0,60'ın üzerinde olan bu değerler de kabul edilebilir sınırlar içerisinde yer almakta ve oldukça güvenilir bulunmaktadır (Kalaycı, 2005: 405). Tablo 2 incelendiğinde Birleşik Güvenirlik (CR) değerlerinin 0,791 ile 0,843 arasında olduğu 


\section{E. Özdemir - S. K1lıç - M. A. Çakırer 11/4 (2019) 2528-2545}

görülmektedir. Tablodaki güvenilirlik değerleri genel olarak incelendiğinde çalışmanın iç tutarlılık güvenirliğinin sağlandığı ifade edilebilir.

Bu çalışmada, ayrışma geçerliliğinin belirlenmesinde Fornell ve Larcker (1981) ile Henseler ve arkadaşları (2015: 116) tarafından önerilen kriterler kullanılmıştır. Ayrışma geçerliliğ̈i, kavramsal olarak benzer olan iki yapının farklılıklarının derecesinin ölçümünde kullanılmaktadır. Fornell ve Larcker (1981) kriterine göre araştırmada yer alan boyutların AVE değerlerinin karekökü, bu boyutların birbirleri arasındaki korelasyondan yüksek olmalıdır. Tablo 3' de Fornell ve Larcker (1981) kriterine göre yapılan ayrışma geçerliliği analiz sonuçları görülmektedir.

Tablo 3. Fornell - Larcker Kriterine Göre Ayrışma Geçerliliği Sonuçları

\begin{tabular}{|l|c|c|c|c|}
\hline & $\begin{array}{c}\text { Kredi Kartıyla } \\
\text { Satın } \\
\text { Alabilme }\end{array}$ & $\begin{array}{c}\text { Plansız Satın } \\
\text { Alma } \\
\text { Davranı̧ı }\end{array}$ & $\begin{array}{c}\text { Satın Alma } \\
\text { Sonrası } \\
\text { Pişmanlık } \\
\text { Davranışı }\end{array}$ & $\begin{array}{c}\text { Satış } \\
\text { Promosyonları }\end{array}$ \\
\hline Kredi Kartıyla Satın Alabilme & $\mathbf{0 , 7 1 9}$ & & & \\
\hline Plansız Satın Alma Davranışı & 0,493 & $\mathbf{0 , 7 2 0}$ & & \\
\hline Satın Alma Sonrası Pişmanlık Davranışı & 0,406 & 0,287 & $\mathbf{0 , 7 4 8}$ & \\
\hline Satış Promosyonları & 0,322 & 0,434 & 0,331 & $\mathbf{0 , 7 9 5}$ \\
\hline
\end{tabular}

Not: Tabloda koyu renkli ve kalın olarak yazılan rakamlar AVE'nin karekök değerleridir.

Tablo 3 incelendiğinde, her bir boyutun açılanan ortalama varyans (AVE) değerinin karekökünün diğer boyutlarla olan korelasyondan yüksek olduğu görülmektedir. Dolayısıyla Fornell ve Larcker (1981) tarafından önerilen kriterin sağlandığ 1 ifade edilebilir.

Henseler ve arkadaşları (2015) tarafından önerilen HTMT kriteri (Heterotrait-Monotrait Ratio), araştırmada yer alan tüm değişkenlere ait ifadelerin korelasyonlarının ortalamasının aynı değişkene ait ifadelerin korelasyonlarının geometrik ortalamalarına oranlarını ifade etmektedir. Henseler ve arkadaşları (2015) çalışmalarında HTMT değerinin 0,85'in altında olması gerektiğini ancak benzer içeriğe sahip boyutlar arasındaki HTMT değerinin 0,90'a kadar çıabileceğini belirtmişlerdir. Tablo 4'de ayrışma geçerliliğine ilişkin HTMT değerleri görülmektedir.

Tablo 4. HTMT Kriterine Göre Ayrışma Geçerliliği Sonuçları

\begin{tabular}{|l|c|c|c|c|}
\hline & $\begin{array}{c}\text { Kredi Kartıyla } \\
\text { Satın } \\
\text { Alabilme }\end{array}$ & $\begin{array}{c}\text { Plansız } \\
\text { Satın Alma } \\
\text { Davranışı }\end{array}$ & $\begin{array}{c}\text { Satın Alma } \\
\text { Sonrası Pişmanlık } \\
\text { Davranışı }\end{array}$ & $\begin{array}{c}\text { Satış } \\
\text { Promosyonları }\end{array}$ \\
\hline Kredi Kartıyla Satın Alabilme & & & & \\
\hline Plansız Satın Alma Davranışı & 0,658 & & & \\
\hline Satın Alma Sonrası Pişmanlık Davranışı & 0,581 & 0,413 & & \\
\hline Satış Promosyonları & 0,419 & 0,562 & 0,477 & \\
\hline
\end{tabular}

Tablo 4 incelendiğinde analizde yer alan boyutların HTMT değerlerinin eşik değerin oldukça altında olduğu görülmektedir. Bu nedenle Henseler ve arkadaşları (2015) tarafından önerilen HTMT kriterine ilişkin şartların da sağlandığ 1 ifade edilebilir. Tablo 3 ve Tablo 4 birlikte değerlendirildiğinde, bu araştırmada yer alan boyutlar arasında ayrışma geçerliliğinin sağlandığı ifade edilebilir. Sonuç olarak, araştırma boyutları yapısal eşitlik modellemesi analizi yapmaya uygun bulunmuştur.

\subsection{Yapısal Eşitlik Modellemesi (YEM) Analizi Sonuçları}

Araştırma modelinin güvenilirliğini ve geçerliliğinin analizinden sonra hipotezleri test etmek amaciyla önerilen araştırma modeli yapısal eşitlik modeli analiziyle incelenmiştir. Modelde satış promosyonları ve kredi kartıyla satın alabilme boyutları egzojen değişkenleri oluşturmaktadır. Modelde yer alan plansız satın alma davranışı ve satın alma sonrası pişmanlık davranışı ise endojen değişkenleri oluşturmaktadır. Araştırma modelinin analiz edilmesinde kısmi en küçük kareler yol analizi (PLS-SEM) kullanılmıştır. Modelin değerlendirilmesinde $R^{2}, \beta$ ve $t$-değerleri ( $t$ değeri $\left.>1,96\right)$ gibi temel ölçümler ile tahmin gücü $\left(Q^{2}\right)$ ve etki büyüklüğü $\left(\mathrm{f}^{2}\right)$ değerleri incelenmiştir. Ölçüm modeli için PLS algoritması, tahmin gücü $\left(\mathrm{Q}^{2}\right)$ değerini hesaplamak için ise Blindfolding analizi çalıştırılmıştır. PLS yol katsayılarının anlamlılıklarını ölçmek için 
E. Özdemir - S. Kılıç - M. A. Çakırer 11/4 (2019) 2528-2545

yeniden örnekleme (bootstrapping) tekniğiyle örneklemden 5000 alt örneklem alınarak $t$ değerleri yeniden hesaplanmıştır. Şekil 2'de araştırma modelinin aracı değişken eklenmiş yapısal eşitlik modellemesi (PLS-SEM) analiz sonuçları görülmektedir.

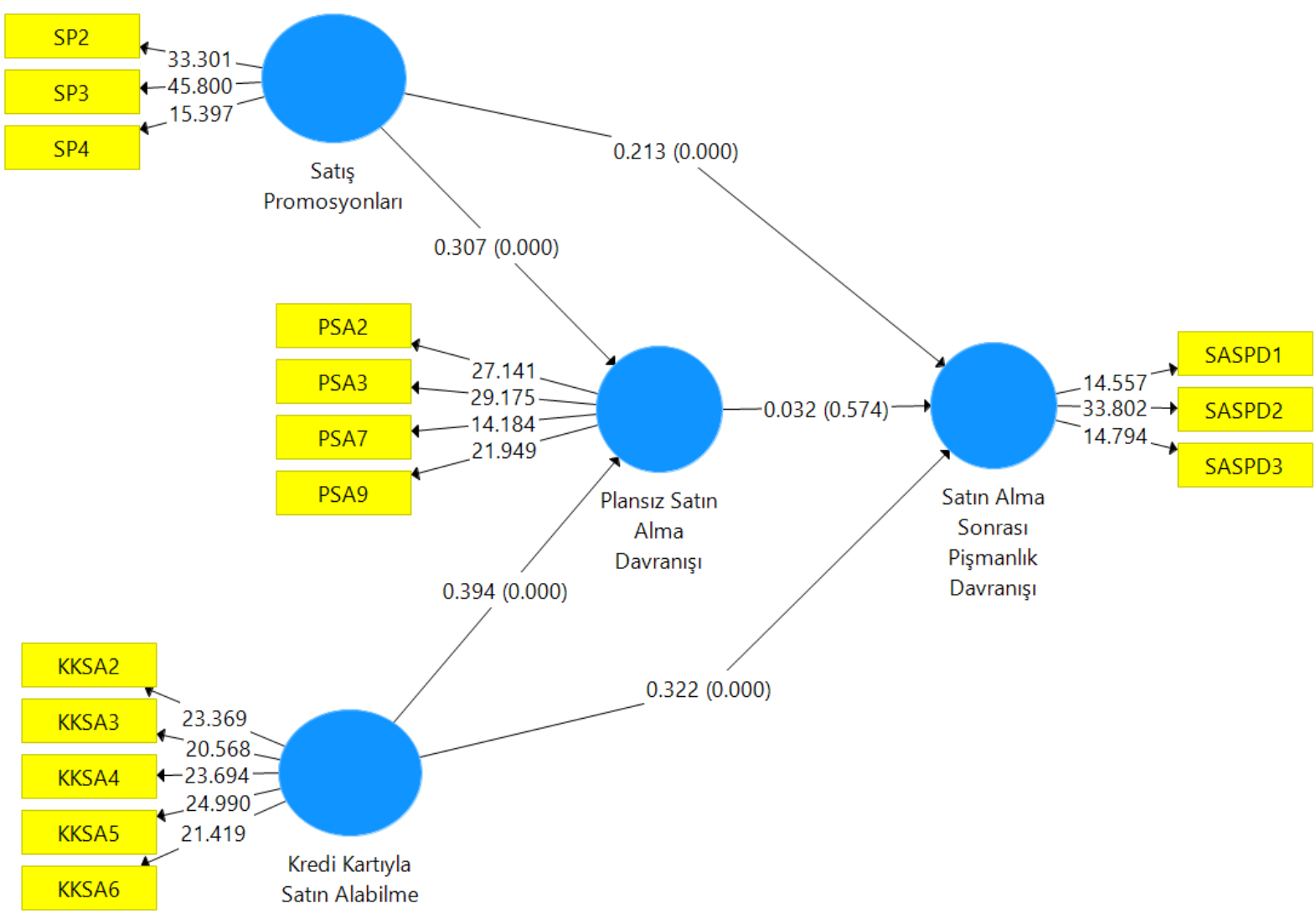

Şekil 2. Aracı Değişken Eklenmiş Yapısal Eşitlik Modeli

Yapısal eşitlik modellemesi analiz sonuçları Tablo 5'de görülmektedir.

Tablo 5. Yapısal Eşitlik Modellemesi Analiz Sonuçları

\begin{tabular}{|c|c|c|c|c|c|c|}
\hline 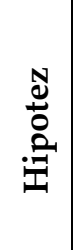 & Yollar & 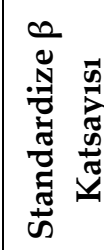 & 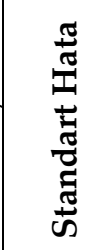 & 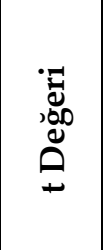 & 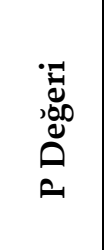 & 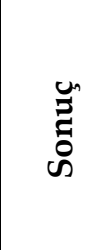 \\
\hline 1 & Satış Promosyonları $\rightarrow$ Plansız Satın Alma Davranışı & 0,305 & 0,044 & 6,956 & 0,000 & Kabul \\
\hline 2 & Kredi Kartıyla Satın Alabilme $\rightarrow$ Plansız Satın Alma Davranışı & 0,394 & 0,049 & 8,056 & 0,000 & Kabul \\
\hline 3 & Satış Promosyonları $\rightarrow$ Satın Alma Sonrası Pişmanlık Davranışı & 0,222 & 0,049 & 4,510 & 0,000 & Kabul \\
\hline 4 & $\begin{array}{l}\text { Kredi Kartıyla Satın Alabilme } \rightarrow \text { Satın Alma Sonrası Pişmanlık } \\
\text { Davranışı }\end{array}$ & 0,334 & 0,045 & 7,394 & 0,000 & Kabul \\
\hline 5 & $\begin{array}{l}\text { Plansız Satın Alma Davranışı } \rightarrow \text { Satın Alma Sonrası Pişmanlık } \\
\text { Davranışı }\end{array}$ & 0,041 & 0,053 & 0,771 & 0,441 & Red \\
\hline 6 & $\begin{array}{l}\text { Satış Promosyonları } \rightarrow \text { Plansız Satın Alma Davranışı } \rightarrow \text { Satın Alma } \\
\text { Sonrası Pişmanlık Davranışı }\end{array}$ & 0,010 & 0,018 & 0,542 & 0,588 & Red \\
\hline 7 & $\begin{array}{l}\text { Kredi Kartıyla Satın Alabilme } \rightarrow \text { Plansız Satın Alma Davranışı } \rightarrow \\
\text { Satın Alma Sonrası Pişmanlık Davranışı }\end{array}$ & 0,013 & 0,023 & 0,550 & 0,582 & Red \\
\hline
\end{tabular}

Aracılık etkisinin araştıılması için ilk aşamada aracı değişken olan plansız satın alma davranışlan boyutu araştırma modeline katılmadan yol katsayılarının anlamlılığı test edilmiştir. Yukarıdaki tablo 5'de yer alan ilk beş hipotezin değerleri aracısız modeldeki sonuçları göstermektedir. Dolayısıyla buradaki sonuçlar Şekil 


\section{E. Özdemir - S. Kılıç - M. A. Çakırer 11/4 (2019) 2528-2545}

1'de verilen aracı değişken eklenmiş nihai modelin analiz sonuçlarındaki değerlerden farklılık göstermektedir. $\mathrm{Bu}$ anlamda yukarıdaki tablo 5 incelendiğinde, $\mathrm{H}_{1}$ hipotezini ifade eden satış promosyonlarının plansız satın alma davranışı üzerindeki etkisi yaklaşık 0,31 bulunmuştur. $H_{1}$ hipotezinin anlamlılık değeri $p=0,000(p<0,05)$ olduğu için bu etki anlamlı bir etkiye sahiptir. Dolayısıyla önerilen $\mathrm{H}_{1}$ hipotezi kabul edilmiştir. $\mathrm{H}_{2}$ hipotezini ifade eden kredi kartıyla satın alabilmenin plansız satın alma davranışı üzerindeki etkisi de yaklaşık 0,39'dur. $\mathrm{H}_{2}$ hipotezinin anlamlılık değeri de $\mathrm{p}=0,000(\mathrm{p}<0,05)$ olduğu için bu etki de anlamlı bir etkiye sahiptir. Dolayısıyla önerilen $\mathrm{H}_{2}$ hipotezi de kabul edilmiştir. Satış promosyonlarının satın alma sonrası pişmanlık davranışı üzerindeki etkisini ifade eden $\mathrm{H}_{3}$ hipotezinin anlamlılık değeri $\mathrm{p}=0,000(\mathrm{p}<0,05)$ bulunduğu için önerilen hipotez kabul edilmiştir. Bu hipoteze ilişkin etki oranını ifade eden standardize ßeta katsayısı incelendiğinde, satış promosyonlarının satın alma sonrası pişmanlık davranışı üzerinde 0,22 düzeyinde bir etkiye sahip olduğu görülmektedir. Kredi kartıyla satın alabilmenin satın alma sonrası pişmanlık davranışı üzerindeki etkisini ifade eden $\mathrm{H}_{4}$ hipotezinin anlamlılık değeri de $\mathrm{p}=0,000(\mathrm{p}<0,05)$ bulunmuştur. Dolayısıyla önerilen bu hipotez de kabul edilmiştir. $\mathrm{H}_{4}$ hipotezine ilişkin etki oranını ifade eden standardize ßeta katsayısı incelendiğinde ise kredi kartıyla satın alabilmenin satın alma sonrası pişmanlık davranışı üzerinde 0,33 düzeyinde bir etkiye sahip olduğu görülmektedir. Plansız satın alma davranışının satın alma sonrası pişmanlık davranışı üzerindeki doğrudan etkisini ifade eden $\mathrm{H}_{5}$ hipotezinin anlamlılık değeri ise ( $\mathrm{p}=0,441$ $(p<0,05)$ bulunmuştur. Dolayısıyla önerilen bu hipotez kabul edilmemiştir. Bir diğer ifadeyle plansız satın alma davranışının satın alma sonrası pişmanlık davranışı üzerinde doğrudan olarak herhangi bir etkisi bulunmamaktadir.

İkinci aşamada plansız satın alma davranışı aracı değişken olarak modele dâhil edilmiş ve oluşturulan aracılı modelin yol katsayılarının anlamlılığı test edilmiştir. Plansız satın alma davranışının satış promosyonları ile satın alma sonrası pişmanlık davranışı arasındaki aracılık etkisi $p=0,588(p<0,05)$ olduğu için anlamlı bulunmamıştır. Benzer şekilde plansız satın alma davranışının kredi kartıyla satın alabilme ile satın alma sonrası pişmanlık davranışı arasındaki aracılık etkisi de $\mathrm{p}=0,588(\mathrm{p}<0,05)$ olduğu için anlamlı bulunmamıştır. Aracı değişken olan plansız satın alma davranışının bağımlı değişken olan satın alma sonrası pişmanlık davranışı üzerinde anlamı etkisinin olmaması nedeniyle aracılık etkisinden söz edilememektedir. $\mathrm{Bu}$ nedenle araştırmanın 6. ve 7. hipotezleri desteklenmemiştir. Bir diğer ifadeyle satış promosyonlarının ve kredi kartıyla satın alabilme seçeneklerinin tüketicilerin satın alma sonrası pişmanlık davranışı üzerinde sadece doğrudan etkiye sahip olduğu ifade edilebilir.

Aşağıdaki tablo $6^{\prime}$ da yapısal eşitlik modellemesinin testinde $\mathrm{R}^{2}, \mathrm{f}^{2}, \mathrm{Q}^{2}$ ve VIF değerleri verilmekte ve aşağıda elde edilen sonuçlar değerlendirilmektedir.

Tablo 6. Yapısal Eşitlik Modelinin $\mathrm{R}^{2}$, f², $\mathrm{Q}^{2}$, VIF Analiz Sonuçları

\begin{tabular}{|c|c|c|c|c|c|}
\hline 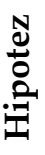 & Yollar & $\mathbf{R}^{2}$ & $\mathbf{f}^{2}$ & $Q^{2}$ & VIF \\
\hline 1 & Satış Promosyonları $\rightarrow$ Plansız Satın Alma Davranışı & \multirow{2}{*}{0,327} & 0,125 & \multirow{2}{*}{0,158} & 1,115 \\
\hline 2 & Kredi Kartıyla Satın Alabilme $\rightarrow$ Plansız Satın Alma Davranışı & & 0,207 & & 1,115 \\
\hline 3 & Satış Promosyonları $\rightarrow$ Satın Alma Sonrası Pişmanlık Davranışı & \multirow{5}{*}{0,210} & 0,046 & \multirow{5}{*}{0,108} & 1,255 \\
\hline 4 & $\begin{array}{l}\text { Kredi Kartıyla Satın Alabilme } \rightarrow \text { Satın Alma Sonrası Pişmanlık } \\
\text { Davranışı }\end{array}$ & & 0,097 & & 1,346 \\
\hline 5 & $\begin{array}{l}\text { Plansız Satın Alma Davranışı } \rightarrow \text { Satın Alma Sonrası Pişmanlık } \\
\text { Davranışı }\end{array}$ & & 0,001 & & 1,486 \\
\hline 6 & $\begin{array}{l}\text { Satış Promosyonları } \rightarrow \text { Plansız Satın Alma Davranışı } \rightarrow \text { Satın Alma } \\
\text { Sonrası Pişmanlık Davranışı }\end{array}$ & & & & \\
\hline 7 & $\begin{array}{l}\text { Kredi Kartıyla Satın Alabilme } \rightarrow \text { Plansız Satın Alma Davranışı } \rightarrow \text { Satın } \\
\text { Alma Sonrası Pișmanlık Davranıșı }\end{array}$ & & & & \\
\hline
\end{tabular}

Tablo 6 incelendiğinde, tüm değişkenlere ait VIF değerlerinin eşik değer olan 5'in (Ali vd., 2018: 529; Garson, 2016: 77; Hair vd., 2011: 145) altında olduğu görülmektedir. Bu nedenle değişkenler arasında doğrusallık problemi olmadığı ifade edilebilir. İçsel modelin analizinde Hair ve arkadaşları (2017) her bir dışsal gizil değişkenin açıklanan varyansını ifade eden $\mathrm{R}^{2}$ değerinin de analiz edilmesini önermektedir. Yapısal modeldeki endojen gizli değişkenler için $\mathrm{R}^{2}$ değerleri $0,75,0,50$ ve 0,25 olduğunda bu değerler sırasıyla büyük, 


\section{E. Özdemir - S. Kılıç - M. A. Çakırer 11/4 (2019) 2528-2545}

orta veya zayıf olarak tanımlanmaktadır (Hair vd., 2011: 145). Modele ait elde edilen $\mathrm{R}^{2}$ değerleri incelendiğinde, satış promosyonları ve kredi kartıyla satın alabilme egzojen boyutlarının tüketicilerin plansız satın alma davranışının yaklaşık \%33'ünü açıkladığı görülmektedir. Satış promosyonları, kredi kartıyla satın alabilme ve plansız satın alma davranışı boyutlarının tüketicilerin satın alma sonrası pişmanlık davranışını açıklama oranı ise \%21'dir. Her iki $\mathrm{R}^{2}$ değeri de endojen değişkenin zayıf açıklandığını göstermektedir.

Hair ve arkadaşları (2017) çalışmalarında $\mathrm{R}^{2}$ ye ek olarak reflektif içsel modelin değerlendirilmesinde $\mathrm{f}^{2}$ ve $\mathrm{Q}^{2}$ değerlerinin de incelenmesi gerektiğini ifade etmektedirler. Etki büyüklüğü olarak ifade edilen $\mathrm{f}^{2}$ değeri, dişsal gizil değişkendeki açıklanamayan kısmının varyans oranına bağlı olarak $\mathrm{R}^{2}$ 'deki artışın hesaplanmasını ifade etmektedir. $\mathrm{f}^{2}$ değerlerine bakılarak tahmin yapılarının etki büyüklüğü değerlendirilmektedir. Cohen (1988) çalışmasında, $\mathrm{f}^{2}$ değerlerini $0.02,0.15$ ve 0.35 aralığında olduğunda sırasıyla küçük, orta ve büyük etki boyutları olarak iade etmektedir. Bir diğer ifadeyle $\mathrm{f}^{2}$ değerleri 0,02 - 0,15 arasında ise küçük; 0,15 - 0,35 arasında ise orta; 0,35 ve üzerinde ise yüksek etki oranı olarak ifade edilmektedir. Tablo 6 incelendiğinde, plansız satın alma davranışı üzerinde satış promosyonlarının düşük (f² değeri 0,125$)$, kredi kartıyla satın alabilmenin ise orta ( $f^{2}$ değeri 0,207 ) düzeyde etki büyüklügüne sahip olduğu görülmektedir. Satın alma sonrası pişmanlık davranışı üzerinde satış promosyonlarının ( $f^{2}$ değeri 0,046 ) ve kredi kartıyla satın alabilmenin ise ( $\mathrm{f}^{2}$ değeri 0,097$)$ düşük etki büyüklüğüne sahip olduğu görülmektedir. Plansız satın alma davranışının satın alma sonrası pişmanlık davranışı üzerindeki etki büyüklüğü ise (f² değeri 0,001$)$ hemen hemen yoktur.

Blindfolding analizi sonucunda bulunan $\mathrm{Q}^{2}$ değeri ise, verilen bir gösterge bloğuna ilişkin bir boyutun verilerini modele dahil etmeden modelin tahmini gücünü değerlendirmektedir (Ali vd., 2016: 463). Kestirimsel örneklemin tekrar kullanım tekniği olan $\mathrm{Q}^{2}$ tahmin gücü düzeyinin belirlenmesinde kullanılan bir kriterdir. Modelin tahmin gücüne sahip olabilmesi için $\mathrm{Q}^{2}>0$ olması gerekmektedir. Elde edilen sıfırdan büyük $\mathrm{Q}^{2}$ değerleri, eksojen yapıların söz konusu endojen yapı için tahmin gücüne sahip olduğunu göstermektedir (Hair vd., 2011: 145; Peng ve Lai, 2012: 473). Tablo 6 incelendiğinde, plansız satın alma davranışı üzerinde satış promosyonları ve kredi kartıyla satın alabilme boyutlarının $\mathrm{Q}^{2}$ değeri 0,158; satın alma sonrası pişmanlık davranışı üzerinde satış promosyonları, kredi kartıyla satın alabilme, plansız satın alma davranışı ile dolaylı etkilerin $\mathrm{Q}^{2}$ değerleri 0,108 bulunmuştur. Bulunan $\mathrm{Q}^{2}$ değerleri sıfırdan büyük olduğu için modelin tahmin gücüne sahip olduğu ifade edilebilir.

\section{4. Çoklu Grup Analiz Sonuçları}

Araştırma modelinde yer alan son hipotez modelde yer alan doğrudan etkilerde cinsiyetin düzenleyici rolüne ilişkindir. Bu amaçla araştırma modelinin cinsiyete göre farklılaşıp farklılaşmadığı da Smart PLS çoklu grup analiziyle araştırılmıştır. Kategorik değişken olan cinsiyette erkeklerin sayısı N=227, kadınların sayısı da $\mathrm{N}=176$ 'dır. Yapısal modelde yer alan ilişkiler cinsiyete göre test edilmiştir. Cinsiyetin düzenleyici değişken olarak ele alındığı çalışmada bulunan sonuçlar aşağıdaki tablo 7'de verilmektedir.

Tablo 7. Cinsiyet Düzenleyici Değişkenine Göre Çoklu Grup Yapısal Eşitlik Analizi Sonuçları

\begin{tabular}{|c|c|c|c|c|c|c|c|}
\hline $\begin{array}{l}N \\
\stackrel{0}{0} \\
\stackrel{2}{0}\end{array}$ & Yollar & 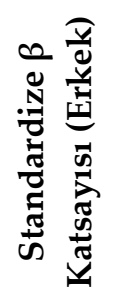 & 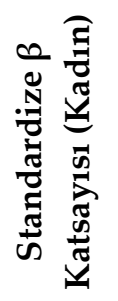 & 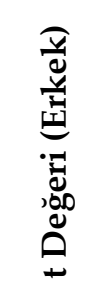 & 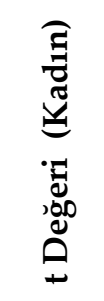 & 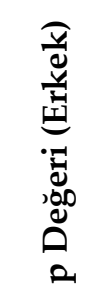 & 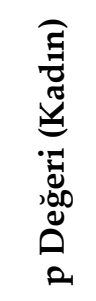 \\
\hline $\mathbf{H}_{8 \mathbf{a}}$ & $\begin{array}{l}\text { Satış Promosyonları } \rightarrow \text { Plansız Satın Alma } \\
\text { Davranışı }\end{array}$ & 0,239 & 0,414 & 3,855 & 7,126 & 0,000 & 0,000 \\
\hline $\mathrm{H}_{8 \mathrm{~b}}$ & $\begin{array}{l}\text { Kredi Kartıyla Satın Alabilme } \rightarrow \text { Plansız } \\
\text { Satın Alma Davranışı }\end{array}$ & 0,463 & 0,316 & 7,606 & 4,135 & 0,000 & 0,000 \\
\hline $\mathbf{H}_{8 \mathrm{c}}$ & $\begin{array}{l}\text { Plansız Satın Alma Davranışı } \rightarrow \text { Satın Alma } \\
\text { Sonrası Pişmanlık Davranışı }\end{array}$ & 0,004 & 0,069 & 0,052 & 0,781 & 0,959 & 0,435 \\
\hline $\mathrm{H}_{8 \mathrm{~d}}$ & $\begin{array}{l}\text { Satış Promosyonları } \rightarrow \text { Satın Alma Sonrası } \\
\text { Pişmanlık Davranışı }\end{array}$ & 0,294 & 0,068 & 4,263 & 0,792 & 0,000 & 0,428 \\
\hline $\mathrm{H}_{8 \mathrm{e}}$ & $\begin{array}{l}\text { Kredi Kartıyla Satın Alabilme } \rightarrow \text { Satın Alma } \\
\text { Sonrası Pişmanlık Davranışı }\end{array}$ & 0,301 & 0,397 & 4,711 & 5,647 & 0,000 & 0,000 \\
\hline
\end{tabular}




\section{E. Özdemir - S. Kılıç - M. A. Çakırer 11/4 (2019) 2528-2545}

Tablo 7 incelendiğinde, plansız satın alma davranışının satın alma sonrası pişmanlık davranışı üzerindeki etkisinin cinsiyet açısından anlamsız çıktığı görülmektedir. Satın alma sonrası pişmanlık davranışı üzerinde satış promosyonlarının etkisi ise her iki cinsiyet açısından farklı anlamlılık düzeyine sahiptir. Bu ilişki erkekler için $p=0,000(p<0,05)$ olduğu için anlamlı iken, kadınlar için anlamlılık değeri $p=0,428(p<0,05)$ olduğu için anlamlı değildir. Bir diğer ifadeyle satış promosyonları erkek tüketicilerde satın alma sonrası pişmanlık davranışına neden olmaktadır. Standardize ßeta katsayısı incelendiğinde, erkeklerde satış promosyonlarının satın alma sonrası pişmanlık davranışı üzerinde 0,29 düzeyinde bir etkiye sahiptir. Tablo 7 'de her bir ilişkinin erkek ve kadın grubu açısından yol katsayıları ve bu katsayıların anlamlılıkları verilmektedir. Ancak her iki grubun yol katsayıları anlamlı olsa da katsayılar arasında da anlamlı bir farklılık olabilir. Yol katsayıları arasındaki farklılıklar ve bu farklılıkların anlamlılık düzeylerine ilişkin aşağıdaki Tablo 8'de yer alan analiz sonuçları incelenmelidir.

Tablo 8. Yol Katsayıları Arasındaki Farklılıklar ve Farklılıkların Anlamlılık Düzeyleri

\begin{tabular}{|l|l|c|c|c|c|}
\hline \multicolumn{1}{|c|}{ Yollar } & $\begin{array}{c}\text { Yol Katsayıları } \\
\text { Arasındaki } \\
\text { Fark (Kadın - } \\
\text { Erkek) }\end{array}$ & $\begin{array}{c}\text { t Değeri } \\
\text { (Kadın- } \\
\text { Erkek) }\end{array}$ & $\begin{array}{c}\text { p Değeri } \\
\text { (Kadın- } \\
\text { Erkek) }\end{array}$ & Sonuç \\
\hline $\mathbf{H}_{8 \mathbf{a}}$ & $\begin{array}{l}\text { Satış Promosyonları } \rightarrow \text { Plansız Satın Alma } \\
\text { Davranısı }\end{array}$ & 0,175 & 2,014 & $\mathbf{0 , 0 4 5}$ & Kabul \\
\hline $\mathbf{H}_{\mathbf{8 b}}$ & $\begin{array}{l}\text { Kredi Kartıyla Satın Alabilme } \rightarrow \text { Plansız } \\
\text { Satın Alma Davranışı }\end{array}$ & 0,147 & 1,528 & 0,127 & Red \\
\hline $\mathbf{H}_{8 \mathbf{c}}$ & $\begin{array}{l}\text { Plansız Satın Alma Davranışı } \rightarrow \text { Satın } \\
\text { Alma Sonrası Pişmanlık Davranısı }\end{array}$ & 0,065 & 0,551 & 0,582 & Red \\
\hline $\mathbf{H}_{8 \mathbf{d}}$ & $\begin{array}{l}\text { Satış Promosyonları } \rightarrow \text { Satın Alma } \\
\text { Sonrası Pişmanlık Davranışı }\end{array}$ & 0,226 & 2,080 & $\mathbf{0 , 0 3 8}$ & Kabul \\
\hline $\mathbf{H}_{8 \mathbf{e}}$ & $\begin{array}{l}\text { Kredi Kartıyla Satın Alabilme } \rightarrow \text { Satın } \\
\text { Alma Sonrası Pişmanlık Davranışı }\end{array}$ & 0,096 & 1,013 & 0,312 & Red \\
\hline
\end{tabular}

Tablo 8 incelendiğinde, cinsiyet açısından yol katsayıları arasındaki farklılıkların $\mathrm{H}_{8 a}$ hipotezinde $\mathrm{p}=0,045$ $(p<0,05)$ ve $\mathrm{H}_{8 d}$ hipotezinde $\mathrm{p}=0,038(\mathrm{p}<0,05)$ olduğu için bu alt hipotezlerde olduğu görülmektedir. Anlamlılık değeri $p<0,05$ olduğu için bu iki hipotez kabul edilmiştir. Bir diğer ifadeyle cinsiyete göre $\mathrm{H}_{8 a}$ ve $\mathrm{H}_{8 \mathrm{~d}}$ hipotezleri farklılık göstermektedir. Elde edilen sonuçlar yukarıdaki tablo 8' deki sonuçlarla birlikte değerlendirildiğinde, satış promosyonlarının plansız satın alma davranışı üzerindeki etkisinin $\left(\mathrm{H}_{8 a}\right)$ erkeklere göre $(0,239)$ kadınlarda $(0,414)$ daha fazla olduğu ve yol katsayıları arasındaki farkın 0,175 olduğu görülmektedir. Bu fark $\mathrm{p}=0,045$ ( $\mathrm{p}<0,05)$ olduğu için anlamlı bir farktır. Satış promosyonlarının satın alma sonrası pişmanlık davranışı üzerindeki etkisinin $\left(\mathrm{H}_{8 \mathrm{~d}}\right)$ ise kadınlara göre $(0,068)$ erkekler de $(0,294)$ daha fazla olduğu ve yol katsayıları arasındaki farkın 0,226 olduğu görülmektedir. Bu fark p=0,038 ( $<<0,05)$ olduğu için anlamlı bir farktır. Bu iki sonuç birlikte değerlendirildiğinde, satış promosyonlarının plansız satın alma davranışı üzerindeki etkisi kadınlarda daha fazla olurken, satış promosyonlarının satın alma sonrası pişmanlık davranışı üzerindeki etkisi erkeklerde daha fazla olduğu ifade edilebilir. Tablo 8'de görüldüğü üzere diğer hipotezlerde $\left(\mathrm{H}_{8 b}, \mathrm{H}_{8 c}\right.$, $\mathrm{H}$ вe) cinsiyete göre anlamlı bir farklılık bulunmamıştır.

\section{SONUÇ VE TARTIŞMA}

Günümüzde yoğun bir şekilde pazarlama iletişim faaliyetlerine maruz kalan tüketiciler, satın alma kararlarında bazen planlamadıkları satın alımlarda bulunabilmektedirler. Bu plansız satın alma kararlarının alınmasında satış promosyonlarının ve kredi kartı kullanma imkânlarının önemli etkileri olabilmektedir. Tüketiciler bazen bu promosyonlar ve kredi kartı kullanma imkânı sayesinde mutlu oldukları satın alma kararları verirken, bazen de bu satın alma kararları sonrasında pişmanlık yaşayabilmektedir. Bu çalışmada belirtilen bu ilişkilerin bilimsel açıdan ortaya konması amaçlanmıştır. Bu amaç doğrultusunda gerçekleştirilen araştırma sonucunda satış promosyonlarının ve kredi kartıyla alışveriş yapabilmenin tüketicilerin plansız satın alma davranışında ve satın alma sonrası pişmanlık davranışında doğrudan etkisinin olduğu bulunmuştur. Elde edilen bu sonuçlar Karbasivar ve Yarahmadi (2011), Saleh (2012), Tinne (2011) ile Virvilaitė ve arkadaşlarının (2011) çalışmalarıyla tutarlıdır. 


\section{E. Özdemir - S. K1lıç - M. A. Çakırer 11/4 (2019) 2528-2545}

Çalışmada aynı zamanda plansız satın almanın satın alma sonrası pişmanlık davranışını üzerindeki doğrudan etkisi de araştırılmış, ancak anlamlı bir etki bulunmamıştır. Bir diğer ifadeyle plansız satın alma, satın alma sonrası pişmanlık davranışına neden olmamaktadır. Bu sonuç Korur ve Kimzan (2016) ile Wulandari (2016) tarafından yapılan araştırmaların sonuçlarından farklılık göstermiştir. Ancak Handayani ve arkadaşlarının (2018) kadın tüketiciler üzerinde gerçekleştirdikleri ve sonucunda alışverişten zevk almanın ve hoş alışveriş atmosferinin plansız satın almayı etkilediği, bunun sonucunda ise plansız satın almanın mutluluğa etkisinin olduğu bulunduğu sonucuyla örtüşmektedir. Bir diğer ifadeyle araştırmaya katılan cevaplayıcılar plansız satın alma kararlarından pişmanlık duymadıklarını ifade etmişlerdir. Bu sonuç çalışmada plansız satın almanın aracılık etkisinin araştıııldığı hipotezle de desteklenmiştir. Bir diğer ifadeyle satış promosyonları ile satın alma sonrası pişmanlık davranışını ve kredi kartıyla satın alabilme ile satın alma sonrası pişmanlık davranışı arasında plansız satın almanın aracılık etkisi bulunmamıştır. Hâlbuki daha önce analiz edilen önceki hipotezlerde pişmanlık üzerinde satış promosyonlarının ve kredi kartı kullanabilmenin doğrudan etkileri bulunmuştur. Tüketicilerin satış promosyonları ve kredi kartı kullanabilme sayesinde plansız satın alma kararları verebildikleri ancak doğrudan ve aracılı etkiler birlikte değerlendirildiğinde, bu kararlarından pişman olmadıkları ifade edilebilir.

Cinsiyetin modeldeki düzenleyici değişken olarak etkisinin de araştırıldığı analiz sonucunda, satış promosyonlarının plansız satın alma davranışı üzerindeki etkisinin kadınlarda daha fazla olduğu bulunmuştur. Bu sonuç Coley ve Burgess (2003), Torlak ve arkadaşları (2013) ile Muratore (2016) tarafından yapılan araştırmaların sonuçlarıyla örtüşmektedir. Araştırmada bulunan bir diğer sonuç, satış promosyonlarının satın alma sonrası pişmanlık davranışı üzerindeki etkisinin kadınlara göre erkeklerde daha fazla olduğudur. Elde edilen bu sonuç Saleh (2012) tarafından yapılan çalışmanın sonuçlarıyla benzerlik gösterirken, Wulandari (2016) tarafından yapılan çalışmanın sonuçlarından farklılaşmaktadır.

Araştırma sonuçları işletmelerin satış promosyonları ve kredi kartı kullanım uygulamalarıyla tüketicilerin plansız satın alma ve satın alma sonrası pişmanlık davranışlarına etkilerini ortaya koyması açısından önemlidir. Memnuniyet ve sadakat düzeyi yüksek müşterilere sahip olmak isteyen işletme yöneticileri, müşterilerinin satın alma sonrası pişmanlık duymaması için satış promosyonlarını ve kredi kartı seçeneklerini dikkatli kullanmalıdırlar. Bu anlamda tüketicilerin satın alma sonrası neden pişmanlık duyduklarını anlamak, müşterilerin yaşadıkları olumsuz deneyimleri en aza indirmek için çalışmalıdırlar. Yöneticilerin, tüketicilerin yaşadıkları farklı satın alma sonrası pişmanlık biçimleri hakkında daha fazla bir farkındalığa ve bilgiye sahip olmaları, müşterilerinin daha iyi bir tüketim deneyimi yaşamaları için daha doğru stratejiler izlemelerine yardımcı olabilir. Örneğin, müş̧erilerinin öncelikli olarak belirtilen ürün seçeneklerinden dolayı pişmanlık duyduklarını bilirlerse, dikkatlerini ürünlerini geliştirmeye ve müşterilerine farklı seçenekler sunmaya (örneğin daha iyi özellikler, daha ucuz fiyatlar) yöneltebilirler. Müşterilerinin, süreçten dolayı pişmanlık duyduklarını bilirlerse, müşterilerine karar alma sürecinde yardımcı hizmetler sunarak ve bilgiye erişimi kolaylaştırarak yardımcı olabilirler. Özetle, satın alma kararlarında hangi unsurların pişmanlık duyulmasına neden olduğu bilinirse pişmanlık boyutunun azaltılması için çalışılabilir (Lee ve Cotte, 2009:461). Bu sayede tüketicilerin işletmeye ve markaya yönelik sadakatleri arttırılabilir (Saleh, 2012). Bu noktada bu çalışmada ele alınan satış promosyonlarının ve kredi kartı kullanım imkânlarının dikkatli planlanması gereklidir. Çalışma sonucunda da görüldüğü gibi bu iki faktör tüketicilerin plansız satın almasına neden olduğu için işletme adına yararlı iken, satın alma sonrası pişmanlık duyulması açısından da işletme için sadakati azaltması adına zararlı olabilmektedir. Bu nedenle özellikle satış anında tüketicilerin plansız da olsa doğru karar verdiklerini kendilerine hissettirecek satış tekniklerinin uygulanması ve tüketicinin kazan/kazan duygusunu hissetmesi sağlanmalıdır.

Tüketicilerin plansız satın alma kararlarını arttırmak için çeşitli uygulamalar daha dikkatli planlanabilir. Örneğin çekici bir dekor, uygun ışıklandırma, yaratıcı tanzim-teşhir, ruh hali ve duygulara hitap eden müzik ve hoş koku gibi atmosfer unsurları ile mağaza içi duyurular kadın tüketicilerin plansız satın alımlarını artırabilir. Erkek tüketiciler için ise ürün karması, tanzim-teşhirde ve promosyonel faaliyetlerde bilişsel ve duyusal unsurların olması ve ürünün fonksiyonelliğinin vurgulanması plansız satın almayı arttırabilir. Bazı ürünlerin plansız olarak daha fazla alınması sebebiyle, bu ürünlerin tanzim-teşhirine önem verilmesi plansız satın alma miktarını artırabilir. 24 saat açık perakendecilik, kredi kartlarının kabulü ve para iade garantilerinin verilmesi gibi uygulamalar da plansız satın almaları arttırabilir (Coley ve Burgess, 2003: 293-294). Ayrica müşterilere yardımsever ve saygılı davranmaları ile müşterinin istenen ürünü bulmalarına ve ulaşmalarına 


\section{E. Özdemir - S. Kılıç - M. A. Çakırer 11/4 (2019) 2528-2545}

yardımcı olmalarını sağlamak için satış personelleri eğitilmelidir. Ayrıca satış elemanlarının tüketicilerin tercihlerine değer vermesi ve işletmelerinden alışveriş yaptıkları için kendilerine teşekkür edilmesi de sağlanmalıdır (Mihić ve Kursan, 2010: 59-60). Bu tür çabalar tüketicilerin plansız satın alımda bulunmalarını sağlayabilir. Ancak bu noktada tüketicilerin satın alma sonrası pişmanlık duymamaları için doğru ve dürüst davranılmalıdır.

Bu çalışma sadece Afyonkarahisar'da yaşayan tüketiciler üzerinde yapılmıştır. Gelecekteki çalışmaların farklı örneklemler üzerinde yapılması ve araştırma modeline farklı boyutların eklenmesi sonucunda katma değeri yüksek yeni çalışmalar gerçekleştirilebilir. Ayrıca plansız satın alma ve satın alma pişmanlık davranışı online satın alma kararları için de araştırılmalıdır.

\section{KAYNAKÇA}

Akarsu, T. N. ve Yeniaras, V. (2014). Müslüman dindarlık, plansız alışverişe olan yatkınlık, fiyat-değer bilinci ve alışveriş sonrası pişmanlık durumu: Bir temel düzenleyici model analizi, İktisat, İ̧sletme ve Finans, 29 (343), 9-38.

Akbari A.F. H. and Radmand, L. (2016). Investigation of effects of buyer's post-purchase remorse in products with high levels of rumination (A case study, mobile phone), International Business Management, 10 (7), 1183-1191.

Akçi, Y. ve Kılınç, K. (2016). Tüketicilerin alışveriş sonrası pişmanlıklarının ve gösterdikleri tepkilerinin incelenmesi, İsletme Araştırmaları Dergisi. 8(4), 108-131.

Ali, F., Amin, M. and Cobanoglu, C. (2016). An integrated model of service experience, emotions, satisfaction, and price acceptance: An empirical analysis in the Chinese hospitality industry, Journal of Hospitality Marketing \& Management, 25(4), 449-475.

Ali, F., Rasoolimanesh, S. M., Sarstedt, M., Ringle, C. M. and Ryu, K. (2018). An assessment of the use of partial least squares structural equation modeling (PLS-SEM) in hospitality research, International Journal of Contemporary Hospitality Management, 30 (1), 514-538.

Awan, A. G. and Abbas, N. (2015). Impact of demographic factors on impulse buying behavior of consumers in Multan-Pakistan, European Journal of Business and Management, 7(22), 96-105.

Beatty, S. E. and Ferrell, M. E. (1998). Impulse buying: Modeling its precursors, Journal of Retailing, 74(2), 169-191.

Buchanan, J., Summerville, A., Reb, J. and Lehmann, J. (2016). The regret elements scale: Distinguishing the affective and cognitive components of regret, Judgment and Decision Making, 11(3), 275-286.

Bushra, A. (2015). Consumer culture and post-purchase behavior, The Journal of Developing Areas, 49(6), $15-24$.

Bushra, A. and Bilal, A. (2014). The relationship of compulsive buying with consumer culture and postpurchase regret, Pakistan Journal of Commerce and Social Sciences (PJCSS), 8(3), 590-611.

Chang, Y. P., Gao, Y. and Zhu, D. H. (2015). The impact of product regret on repurchase intention, Social Behavior and Personality: An International Journal, 43(8), 1347-1360.

Clarke, P. and Mortimer, G. (2013). Self-gifting guilt: An examination of self-gifting motivations and postpurchase regret, Journal of Consumer Marketing, 30(6), 472-483.

Clover, V. T. (1951). Relative importance of impulse buying in retail stores, Journal of Marketing, 25(July), 66-70.

Cohen, J. (1988). Statistical power analysis for the behavioral sciences, 2nd ed., Lawrence Erlbaum Associates, USA.

Coley, A. and Burgess, B. (2003). Gender differences in cognitive and affective impulse buying, Journal of Fashion Marketing and Management: An International Journal, 7(3), 282-295. 


\section{E. Özdemir - S. K1lıç - M. A. Çakırer 11/4 (2019) 2528-2545}

Ekeng, A. B., Lifu, F. L. and Asinya, F. A. (2012). Effect of demographic characteristics on consumer impulse buying among consumers of Calabar municipality, Cross River State, Academic Research International, $3(2), 568-574$.

Eren, S. S., Eroğlu, F. and Hacioglu, G. (2012). Compulsive buying tendencies through materialistic and hedonic values among college students in Turkey, Procedia - Social and Behavioral Sciences, 58, 13701377.

Fornell, C. and Larcker, D. F. (1981). Evaluating structural equation models with unobservable variables and measurement error, Journal of Marketing Research, 18(1), 39-50.

Garson, G. D. (2016). Partial least squares: Regression and structural equation model, Statistical Associates Publishing, USA: Asheboro.

Hair, J. F., Black, W.C., Babin, B.J. and Anderson, R.E. (2014). Multivariate data analysis, Pearson Education Limited, Essex.

Hair, J.F., Hult, G.T.M., Ringle, C.M. and Sarstedt, M. (2017). A primer on partial least squares structural equation modeling (PLS-SEM), 2nd ed., Sage, Thousand Oaks, CA.

Hair, J.F., Ringle, C.M. and Sarstedt, M. (2011). PLS-SEM: Indeed a silver bullet, Journal of Marketing Theory and Practice, 19(2), 139-152.

Handayani, W., Anshori, M., Usman, I. and Mudjanarko, S. (2018). Why are you happy with impulse buying? Evidence from Indonesia, Management Science Letters, 8(5), 283-292.

Henseler, J. (2017) Partial Least Squares Path Modeling, Leeflang, P.S.H. and et al. (Eds.), In Advanced Methods for Modeling Markets, International Series in Quantitative Marketing, Springer International Publishing: 361-381.

Henseler, J., Ringle, C.M. and Sarstedt, M. (2015). A new criterion for assessing discriminant validity in variance-based structural equation modeling, Journal of the Academy of Marketing Science, 43(1), 115135.

Husnain, M., Rehman, B., Syed, F. and Akhtar, M. W. (2019). Personal and in-store factors influencing impulse buying behavior among generation Y consumers of small cities, Business Perspectives and Research, 7(1), 92-107.

Imam, F. (2013). Gender differences in impulsive buying behavior and post-purchasing dissonance under incentive conditions. Journal of Business Strategies, 7(1), 23-29.

Kalaycı, S. (2005). SPSS uygulamalı çok değişkenli istatistik teknikleri, Ankara: Asil Yayın Dağıtım.

Karbasivar, A. and Yarahmadi, H. (2011). Evaluating effective factors on consumer impulse buying behavior, Asian Journal of Business Management Studies, 2(4), 174-181.

Korur, M. G. and Kimzan, H. S. (2016). Kompulsif satın alma eğilimi ve alışveriş sonrası pişmanlık ilişkisinde kontrolsüz kredi kartı kullanımının rolü: AVM müşterileri üzerine bir araştırma, Tüketici ve Tüketim Araştırmaları Dergisi, 8(1), 43-71.

Kurt, S. D. ve Bayraktaroğlu, G. (2013). Öteleme davranışı sonucu oluşan pişmanlık: Hazcı ve faydacı ürün karşı1laştırması, Ulusal Pazarlama Kongresi Bildiriler Kitabı, 18, 19-22.

Lee, S. H. and Cotte, J. (2009). Post-purchase consumer regret: Conceptualization and development of the PPCR scale, in NA - Advances in Consumer Research Volume 36, Eds. McGill, A.L. and Shavitt, S., Duluth, MN: Association for Consumer Research, 456-462.

Lim, S. H., Lee, S. and Kim, D. J. (2017). Is online consumers' impulsive buying beneficial for e-commerce companies? An empirical investigation of online consumers' past impulsive buying behaviors, Information Systems Management, 34(1), 85-100.

M'Barek, M. B. and Gharbi, A. (2011). The moderators of post purchase regret, Journal of Marketing Research \& Case Studies, 1-16.

Mihić, M. and Kursan, I. (2010). Assessing the situational factors and impulsive buying behavior: Market segmentation approach, Management: Journal of Contemporary Management Issues, 15(2), 47-66. 


\section{E. Özdemir - S. Kılıç - M. A. Çakırer 11/4 (2019) 2528-2545}

Moakhar, S. V., Shafigh, N., Zerafat, R. and Sohae, R. (2018). The effect of regret determinants on consumers' post-purchase behavior in urban shopping complex building, Management Research and Practice, 10(2), 63-77.

Mohan, G., Sivakumaran, B. and Sharma, P. (2013). Impact of store environment on impulse buying behavior, European Journal of Marketing, 47(10), 1711-1734.

Muratore, I. (2016). Teens as impulsive buyers: What is the role of price?, International Journal of Retail \& Distribution Management, 44(11), 1166-1180.

Ozer, L. and Gultekin, B. (2015). Pre-and post-purchase stage in impulse buying: The role of mood and satisfaction, Journal of Retailing and Consumer Services, 22, 71-76.

Peng, D.X. and Lai, F. (2012). Using partial least squares in operations management research: A practical guideline and summary of past research, Journal of Operations Management, 30 (6), 467-480.

Rasheed, A., Yaqup, R. M. S. and Baig, F. J. (2017). Factors affecting impulse buying behaviors in shopping malls: Evidence from Bahawalpur region, Pakistan Journal of Marketing and Consumer Research, 39, $1-20$.

Rook, D. W. (1987). The buying impulse, The Journal of Consumer Research, 14(2), 189-199.

Rook, D. W. and Gardner, M. P. (1993). In the mood: Impulse buying's affective antecedents, Research in Consumer Behavior, 6(7), 1-28.

Rook, D. W. and Hoch, S. J. (1985). Consuming impulses, Advances in Consumer Research, 12, 23-27.

Saleh, M. A. H. (2012). An investigation of the relationship between unplanned buying and post-purchase regret, International Journal of Marketing Studies, 4(4), 106-120.

Sarstedt, M., Ringle, C. M. and Hair, J. F. (2017). Partial least squares structural equation modeling, Homburg, C. and et al. (Eds.), Handbook of Market Research, Springer International Publishing, 1-40.

Sekaran, U. (2003). Research methods for business: A skill-building approach, (Fourth Edition), John Wiley and Sons.

Stern, H. (1962). The significance of impulse buying today, Journal of Marketing, 26(2), 59- 62.

Tinne, W. S. (2011). Factors affecting impulse buying behavior of consumers at superstores in Bangladesh, ASA University Review, 5(1), 209-220.

Torlak, Ö., Doğan, V. ve Özkara, B. Y. (2013). Üniversite öğrencilerinin yaşamlarında algıladıkları zaman baskısının plansız satın alma eğilimleri üzerindeki etkisi, Pazarlama ve Pazarlama Araştırmaları Dergisi, 12, 1-20.

Unal, S. ve Aydin, H. (2016). Evaluation of consumer regret in terms of perceived risk and repurchase intention, Journal of Global Strategic Management, 2(10), 31-31.

Virvilaite, R., Saladiene, V. and Bagdonaite, R. (2009). Peculiarities of impulsive purchasing in the market of consumer goods, Engineering Economics, 2, 101-109.

Virvilaite, R., Saladienè, V. and Žvinklyte, J. (2011). The impact of external and internal stimuli on impulsive purchasing, Economics \& Management, 16, 1329-1336.

Wulandari, R. (2016). The influence of unplanned buying to post-purchase regret and gender as moderating variable, IRCMB Conferences, http://ircmb.org/galerry/proceedings-2016/, 1-14, (Erişim tarihi: 15 Ağustos 2019). 